\author{
UNIVERSIDADE DE SÃO PAULO \\ INSTITUTO DE QUÍMICA DE SÃO CARLOS
}

\title{
AVALIAÇÃO DE PROCESSOS OXIDATIVOS PARA O TRATAMENTO AMBIENTALMENTE ADEQUADO DE FLUIDOS DE CORTE
}

\section{ELIAS PAULO TESSARO}

Dissertação apresentada ao Programa de Pós-Graduação do Instituto de Química de São Carlos, da Universidade de São Paulo para a obtenção do título de Mestre.

Orientadora: Prof ${ }^{a}$. Dra. Maria Olímpia de Oliveira Rezende

São Carlos

Abril - 2008 
Aos meus pais, Durvalino e Celi, pelo exemplo de vida e por estarem sempre ao meu lado. 


\section{Agradecimentos}

> Às minhas orientadoras, Maria Olímpia e Leny, pela oportunidade, pelos ensinamentos, paciência e pela dedicação.

$>$ À Claudia que esteve sempre me aconselhando e apoiando em todos os momentos.

> À toda minha família que sempre esteve por perto e acompanhou toda minha vida e minhas conquistas até aqui.

> Ao pessoal do Laboratório de Resíduos Químicos: Flávio, Pudim, Sassarico, Bonsai e Maira pela ótima convivência e por de alguma forma, contribuírem para a realização desse trabalho.

> Ao pessoal do Laboratório de Química Ambiental: Diva e Fabiane pela amizade e ajuda nas determinações.

> Ao pessoal da Solução Ambiental - Análises e Consultorias: Rafael, Timel, Fernanda e Lisânias pelo companheirismo e auxilio neste trabalho.

> Ao Núcleo de Manufatura Avançado e Instituto Fabrica do Milênio: Tobias que durante este período muito se dedicou nesta minha caminhada.

> Ao Centro de Capacitação e Pesquisa em Meio Ambiente: Amilcar que ajudou na avaliação do processo foto-Fenton.

> Ao pessoal da república: Luiz (Hemo), Gustavo (Bixo), Paulo (Cachorro) e Leonardo (Gordo) pela amizade e convivência durante esses anos.

> Aos técnicos dos laboratórios de ensino e da central de analises químicas.

$>A$ todos que contribuíram, direta ou indiretamente, para a realização deste trabalho

$>\quad$ Ao CNPq, pelo auxilio financeiro. 


\section{RESUMO}

Durante o processo metalúrgico de usinagem de uma peça ocorre a geração de calor proveniente do atrito ferramenta/peça e cavaco/ferramenta. Para que ocorra uma menor geração de calor possibilitando o manuseio, bem como a minimização na deformação da peça, utilizam-se fluidos, que são soluções lubrificantes à base de óleos, água ou polímeros, podendo ser sintéticos ou não, diminuindo, assim, o coeficiente de atrito reduzindo-se a quantidade de calor gerado no processo. Há uma grande variedade de fluidos de corte disponíveis no mercado que são constituídos por diversos compostos como: aminas, compostos clorados e/ou aromáticos, glicóis, nitrosaminas além da presença de metais provenientes do processo de manufatura, portanto, sem tratamento, não podem ser lançados na rede de esgoto convencional. Atualmente não há um método de tratamento para os fluidos de corte nas indústrias. Nesse contexto, propõe-se um estudo sobre a viabilidade dos tipos de tratamento dos fluidos de corte para uma disposição adequada. Os processos de tratamento propostos neste trabalho compreendem hidrolise ácida e Processo Oxidativo Avançado (POA), mais especificamente, Sistema Fenton, além de propor um tratamento baseado na fotodegradação. A caracterização do fluido antes e após seu tratamento foi realizada por técnicas analíticas e espectrométricas. Os processos oxidativos mostraram-se satisfatórios para o tratamento dos efluentes, reduzindo os níveis de contaminantes ao permitido pela legislação. O processo foto-Fenton mostrou-se mais eficiente que o processo Fenton na oxidação de BTEX e HPAs. Os processos de hidrólise ácida não apresentaram resultados satisfatórios reduzindo apenas os metais aos níveis permitidos para descarte 


\begin{abstract}
During the cutting process, part of the heat generation results from tool-part and chip-tool friction. So that it happens a smaller generation of heat making possible the handling, as well as minimization in the tool deformation, cutting fluids are used, that are the oils base, water or polymeric lubricating solutions, could be synthetic or no, decreasing the attrition coefficient being reduced the amount of heat generated in the process. There is a great variety of cutting fluids that are constituted for several composed as: amines, chlorinated and/or aromatic composed, glycols and nitrosamines besides the presence of metals proceeding of manufacture process, therefore, without a treatment, they cannot be discarded in the conventional sewerage system. At the moment there isn't a treatment method for the cut fluids in the industries. In that context, intends a study about the viability types of cutting fluids treatment for appropriate disposition. Treatment processes proposed in this work understand acid hydrolysis and Advanced Oxidative Process (AOP), more specifically, Fenton System, in addition proposing a treatment based on the photodegradation (photo-Fenton process). The characterization of fluid before and after treatment it was accomplished by analytical and spectrometry techniques. Oxidative processes were exposed satisfactory for cutting fluids treatment, reducing the levels of pollutants to the allowed by the legislation. Photo-Fenton process was shown more efficient than Fenton process in the oxidation of BTEX and PAHs. Acid hydrolysis processes didn't present satisfactory results, just reducing the metals at the levels allowed for discard.
\end{abstract}




\section{LISTA DE ABREVIATURAS E SÍMBOLOS}

$\begin{array}{ll}\text { DBO } & \text { Demanda Bioquímica de Oxigênio } \\ \text { DQO } & \text { Demanda Química de Oxigênio } \\ \text { COT } & \text { Carbono Orgânico Total } \\ \text { CL }_{50} & \text { Concentração Letal } \\ \text { CE }_{50} & \text { Concentração Efetiva } \\ \text { EPIs } & \text { Hidrocarbonetos Policíclicos Aromáticos } \\ \text { HPAs } & \text { Processos Oxidativos Avançados } \\ \text { POA } & \text { Carbono Orgânico Assimilável } \\ \text { COA } & \text { Sulfato Ferroso Amoniacal } \\ \text { FFA } & \text { Droteção Individuais } \\ & \end{array}$

Experimento 01 Hidrólise Ácida (ác. tricloroacético)

Experimento 02 Hidrólise Ácida (ác. tricloroacético + carvão ativo)

Experimento 03 Hidrólise Ácida (cloreto férrico)

Experimento 04 Processo Fenton $\left(\left[\mathrm{Fe}^{2+}\right]=22,5 \mathrm{mmol} \mathrm{L}^{-1},\left[\mathrm{H}_{2} \mathrm{O}_{2}\right]=1100,0 \mathrm{mmol} \mathrm{L}^{-1}\right.$ ) 
Experimento 05 Processo Fenton $\left(\left[\mathrm{Fe}^{2+}\right]=15,0 \mathrm{mmol} \mathrm{L}^{-1},\left[\mathrm{H}_{2} \mathrm{O}_{2}\right]=735,0 \mathrm{mmol} \mathrm{L}^{-1}\right)$

Experimento 06 Processo Fenton $\left(\left[\mathrm{Fe}^{2+}\right]=15,0 \mathrm{mmol} \mathrm{L}^{-1},\left[\mathrm{H}_{2} \mathrm{O}_{2}\right]=600,0 \mathrm{mmol} \mathrm{L}^{-1}\right)$

Experimento 07 Processo Fenton $\left(\left[\mathrm{Fe}^{2+}\right]=10,0 \mathrm{mmol} \mathrm{L}^{-1},\left[\mathrm{H}_{2} \mathrm{O}_{2}\right]=500,0 \mathrm{mmol} \mathrm{L}^{-1}\right)$

Experimento 08 Processo Fenton $\left(\left[\mathrm{Fe}^{2+}\right]=5,0 \mathrm{mmol} \mathrm{L}^{-1},\left[\mathrm{H}_{2} \mathrm{O}_{2}\right]=400,0 \mathrm{mmol} \mathrm{L}^{-1}\right)$

Experimento 09 Processo Fenton $\left(\left[\mathrm{Fe}^{2+}\right]=1,0 \mathrm{mmol} \mathrm{L}^{-1},\left[\mathrm{H}_{2} \mathrm{O}_{2}\right]=200,0 \mathrm{mmol} \mathrm{L}^{-1}\right)$

Experimento 10 Processo Fenton $\left(\left[\mathrm{Fe}^{2+}\right]=0,05 \mathrm{mmol} \mathrm{L}^{-1},\left[\mathrm{H}_{2} \mathrm{O}_{2}\right]=400,0 \mathrm{mmol} \mathrm{L}^{-1}\right)$

Experimento 11 Processo foto-Fenton $\left(\left[\mathrm{Fe}^{2+}\right]=0,05 \mathrm{mmol} \mathrm{L}^{-1},\left[\mathrm{H}_{2} \mathrm{O}_{2}\right]=200,0 \mathrm{mmol} \mathrm{L}{ }^{-1}\right)$

Experimento 12 Processo foto-Fenton $\left(\left[\mathrm{Fe}^{2+}\right]=5,0 \mathrm{mmol} \mathrm{L}^{-1},\left[\mathrm{H}_{2} \mathrm{O}_{2}\right]=400,0 \mathrm{mmol} \mathrm{L}^{-1}\right)$

Experimento 13 Processo foto-Fenton $\left(\left[\mathrm{Fe}^{2+}\right]=1,0 \mathrm{mmol} \mathrm{L}^{-1},\left[\mathrm{H}_{2} \mathrm{O}_{2}\right]=400,0 \mathrm{mmol} \mathrm{L}^{-1}\right)$ 


\section{SUMÁRIO}

\section{LISTA DE FIGURAS}

\section{LISTA DE TABELAS}

CAPÍTULO 1: INTRODUÇÃO ................................................... 01

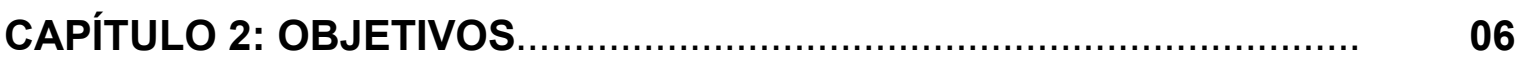

CAPÍTULO 3: REVISÃO BIBLIOGRÁFICA ................................ 07

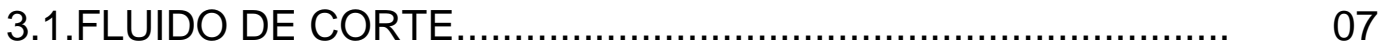

3.2.TIPOS DE FLUIDOS, COMPOSIÇÃO E PROPRIEDADES....... 09

3.3.TOXICIDADE À SAÚDE E MEIO AMBIENTE......................... 10

3.4.RECUPERAÇÃO E TRATAMENTOS................................. 13

3.5.DESCARTE DE FLUIDO DE CORTE INTEGRAL.................. 15

3.6.DESCARTE DE FLUIDOS DE CORTE À BASE DE ÁGUA....... 16

3.7.PROCESSOS OXIDATIVOS AVANÇADOS ............................ 18

a) Sistema Fenton.............................................. 20

b) Sistema foto-Fenton......................................... 21

c) Fotocatálise Heterogênea..................................... 22

d) Sistemas Ozonizados......................................... 22

3.7.1.SISTEMA FENTON ................................................. 23

3.7.2.SISTEMA FOTO-FENTON ....................................... 25

3.7.3.FATORES QUE INTERFEREM NA REAÇÃO.................. 28

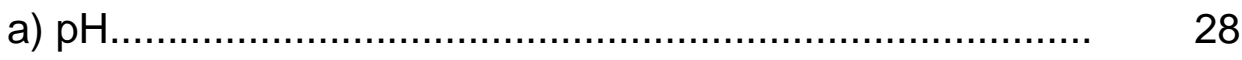

b) Concentração de Íons Ferro.................................... 28 
c) Tipo de Íons Ferro..................................................... 29

d) Concentração de Peróxido de Hidrogênio........................ 29

e) Temperatura .......................................................... 30

f) Tempo de Reação.......................................................... $\quad 30$

CAPÍTULO 4: MÉTODOS DE CARACTERIZAÇÃO.................................. 31

4.1.CARBONO ORGÂNICO TOTAL (COT)................................ 31

4.2.DEMANDA QUÍMICA DE OXIGÊNIO (DQO)....................... 32

4.3.DEMANDA BIOQUÍMICA DE OXIGÊNIO (DBO).................. 33

4.4.ÓLEOS E GRAXAS....................................................... 34

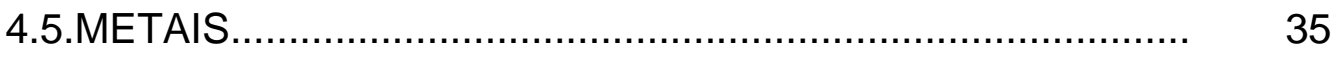

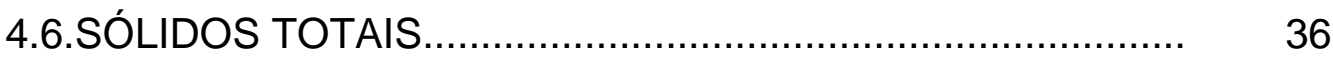

4.7.CROMATOGRAFIA........................................................ 37

CAPÍTULO 5: PROCEDIMENTO EXPERIMENTAL.................................... 42

5.1.HIDRÓLISE ÁCIDA............................................................. 43

5.2.SISTEMA FENTON..........................................................

5.3.SISTEMA FOTO-FENTON............................................... 47

CAPÍTULO 6: RESULTADOS E DISCUSSÃO.......................................... 50

6.1.CARACTERIZAÇÃO DO FLUIDO DE CORTE PRÉ E PÓS PROCESSO DE USINAGEM......................................................... 50

6.2.HIDRÓLISE ÁCIDA........................................................ 52

6.3.PROCESSO FENTON.........................................................

6.4.PROCESSO FOTO-FENTON............................................. 60

CAPÍTULO 7: COMPARAÇÃO DOS MÉTODOS ESTUDADOS................. 63

CAPÍTULO 8: CROMATOGRAFIA......................................................... 68

CAPÍTULO 9: CONCLUSÕES............................................................... 
CAPÍTULO 10: SUGESTÃO PARA TRABALHOS FUTUROS..................... 77

CAPÍTULO 11: REFERÊNCIAS BIBLIOGRÁFICAS................................... 78 


\section{LISTA DE FIGURAS}

Figura 1: Tipos de fluidos de corte existentes no mercado e suas subdivisões.

Figura 2: Band Gap.

Figura 3: Diagrama do processo de hidrólise ácida utilizado no tratamento de resíduos de fluidos de corte.

Figura 4: Diagrama do processo de hidrólise ácida utilizado no tratamento de resíduos de fluidos de corte.

Figura 5: Diagrama do processo de hidrólise ácida utilizado no tratamento de resíduos de fluidos de corte.

Figura 6: Amostra antes (1) e após (2) a hidrólise ácida

Figura 7: Precipitados formados na neutralização do processo da hidrolise ácida: (1) ácido tricloroacético, (2) cloreto férrico e (3) ácido tricloroacético mais carvão ativo.

Figura 8: Formação de precipitado no Processo Fenton.

Figura 9: Redução no COT do experimento 04 em função do tempo

Figura 10: Redução no COT dos experimentos 08, 09 e 10 em função do tempo.

Figura 11: Equipamento usado para a foto-oxidação do resíduo de fluido de 
corte

Figura 12: Redução no COT dos experimentos 11, 12 e 13 em função do tempo

Figura 13: Comparação na redução do COT dos experimentos 08 e 13 em função do tempo.

Figura 14: Análise de BTEX e HPAs antes e após o processo de usinagem: 1 e 2 fluido de corte antes do processo de usinagem - BTEX e HPAs respectivamente; 3 e 4 fluido de corte após o processo de usinagem - BTEX e HPAs respectivamente.

Figura 15: Análise de HPAs para os experimentos utilizando Fenton (Experimento 08, 09 e 10) e Foto-Fenton (Experimento 11, 12 e 13).

Figura 16: Análise de BTEX para os experimentos utilizando Fenton (Experimento 08, 09 e 10) e Foto-Fenton (Experimento 11, 12 e 13).

Figura 17: Cromatograma de massa de amostras de fluido de corte antes (1) e após (2) o processo de usinagem, os espectros de massa estão abaixo de cada cromatograma e representam os cinco primeiros picos do espectro

Figura 18: Cromatograma dos Experimentos 09 ao 13, onde não foi observado a presença de nitrosaminas 


\section{LISTA DE TABELAS}

Tabela 1: Poder de oxidação de espécies reativas em relação ao cloro

Tabela 2: Tempo de retenção obtido para uma mistura de BTEX padrão.

Tabela 3: Tempo de retenção obtido para uma mistura de HPAs padrão.

Tabela 4: Condições experimentais utilizadas para a hidrólise ácida de amostras de fluido de corte.

Tabela 5: Condições experimentais utilizadas para o Processo Fenton em amostras de fluido de corte.

Tabela 6: Condições experimentais utilizadas para o Processo Fenton em amostras de fluido de corte.

Tabela 7: Caracterização química do fluido de corte antes e após utilização no processo de usinagem.

Tabela 8: Caracterização química do fluido de corte após hidrólise ácida

Tabela 9: Caracterização dos metais presentes no precipitado dos testes utilizando hidrólise ácida.

Tabela 10: Caracterização química do fluido de corte após Processo Fenton.

Tabela 11: Caracterização química do fluido de corte após Processo Fenton..... 58

Tabela 12: Caracterização dos metais presentes no precipitado dos testes 
utilizando Processo Fenton.

Tabela 13: Caracterização química do fluido de corte após Processo fotoFenton

Tabela 14: Caracterização dos metais presentes no precipitado dos testes utilizando hidrólise ácida

Tabela 15: Comparação dos resultados obtidos nos diferentes processos de tratamento

Tabela 16: Custo estimado para cada tratamento estudado. 66

Tabela 17: Concentrações de BTEX no resíduo de fluido de corte 70

Tabela 18: Concentração de HPAs no resíduo de fluido de corte. 70

Tabela 19: Concentração de HPAs encontrados no Experimento 09 70 


\section{CAPÍTULO 1: \\ INTRODUÇÃO}

o último século, o desenvolvimento tecnológico nos processos de
manufatura para a obtenção de produtos de melhor qualidade, eficiência econômica e reciclagem nas indústrias, levou à geração de materiais residuais indesejáveis que, conseqüentemente, provocaram acréscimo na emissão de poluentes [1].

Nos últimos 30 anos testemunhamos uma crescente conscientização do frágil estado da maioria das fontes de água potável do planeta. Para minimizar a degradação da nossa hidrosfera, programas educacionais e legislativos estão sendo implementados e duas principais estratégias para o tratamento das águas estão sendo iniciadas: (1) tratamento das águas potáveis, superficiais e subterrâneas poluídas e (2) tratamento químico das águas residuárias contendo compostos biocidas ou não degradáveis [2].

A remoção dos poluentes em águas potáveis pode envolver técnicas adotadas nas regulamentações governamentais como a floculação, filtração, esterilização ou procedimentos de conservação, às quais foram somadas técnicas de tratamento químico que envolve o uso limitado de reagentes [2].

O tratamento químico de águas residuárias, superficiais e subterrâneas contaminadas por biocidas ou compostos não biodegradáveis é parte de uma estratégia, a longo prazo, para melhorar a qualidade das fontes potáveis, eliminando 
materiais tóxicos de origem antropogênica antes de devolver as águas usadas em seu ciclo natural. Solos contaminados podem ser recuperados biologicamente e/ou quimicamente por percolação [2].

A maioria dos poluentes orgânicos são originados do refino de petróleo, da manufatura de produtos químicos, de indústrias carboníferas, de processamento têxtil e papeleiras, da utilização de óleos para transporte e aquecimento, na agricultura tradicional (pesticidas, fertilizantes etc.), além dos efluentes de estações de tratamento de águas residuárias, lançamento incontrolado de resíduos tóxicos e derramamentos acidentais [3].

A poluição causada por esses compostos oferece grave risco, pois deve levar em consideração a toxicidade dos seus componentes. Os efeitos adversos desses compostos na saúde humana são causados pelo uso de fontes de água poluídas ou ingestão de alimentos contaminados por acúmulo de substâncias tóxicas [4].

O controle da poluição tornou-se um negócio complexo e custoso, considerando os custos da instalação e operação de controladores de poluição ou equipamentos de tratamento. Reduzindo a quantidade de poluentes do ambiente, reduzir-se-iam também os custos com controle e tratamento desses resíduos. Isso poderia ser feito trocando-se os processos de produção, os produtos usados, ou ambos, para que os poluentes mais agressivos não fossem produzidos, encontrando substituintes não perigosos para materiais perigosos ou recuperando solventes após o uso [5].

A consciência ambiental que cresce consideravelmente a cada ano, e os problemas com o descarte, pressionado por uma legislação mais severa, obriga as indústrias a se aprofundarem nas questões de compatibilidade ambiental das suas produções. 
Um dos problemas graves inerentes às indústrias metal-mecânicas é o fluido de corte, uma vez que se torna essencial na manufatura das peças, sendo seu descarte cada vez mais complexo, pois a cada nova linha de fluidos fabricados novos compostos são utilizados. Em muitos casos se desconhecem as interações do fluido de corte com o ambiente; essa falta de informação pode, em muitas vezes, causar a contaminação da água e solo, além de ser prejudicial à saúde do trabalhador.

Como parte integrante dos processos de manufatura industrial, encontram-se os processos de usinagem, que basicamente consistem em dar forma a peças e acessórios pela remoção de material. Na grande maioria dos processos de usinagem é necessário o emprego de um agente - fluido de corte - que desempenha diversas funções com o propósito de se obter benefícios tecnológicos no processo [1].

Ambientalmente, os fluidos de corte estão presentes nas peças e nos cavacos durante e após a usinagem. Os principais problemas originados desses cavacos são o derramamento de fluidos de corte no meio durante a armazenagem e o transporte dos mesmos, com conseqüente possível contaminação do solo, lençol freático e rede de coleta de esgoto. O fato agrava-se quando o depósito é feito em locais sem cobertura, onde a água proveniente das chuvas arrasta para o solo e para os sistemas de água fluvial e subterrâneos diversos contaminantes e compostos químicos constituintes dos fluidos de corte, que podem ser solúveis ou emulsionáveis em água, ocasionando danos ambientais graves. Além desse aspecto, custos elevados de disposição final e tratamento de fluidos de corte, aliados ao controle de resíduos industriais, servem de estímulo para que usuários procedam de maneira inadequada no momento da disposição desses resíduos [1]. 
Dentre os diversos tipos de poluentes presentes nos fluidos de corte, encontram-se os óleos e graxas, que apresentam alta toxicidade e não são degradados por processos microbiológicos. O uso de processos físico-químicos como floculação, adsorção, stripping, coagulação eletroquímica e filtração não são destrutivos; embora minimizem os efeitos danosos da poluição graças à redução do volume da amostra, o problema da disposição final permanece [6].

Portanto, a utilização de fluidos de corte no processo de usinagem faz da indústria metal-mecânica um potencial agressor ao ambiente. São vários os problemas decorrentes desta utilização, que vão desde a geração de efeitos nocivos ao trabalhador até a agressão do meio ambiente. Esse impacto ambiental é assistido pela Legislação Federal, na Lei $n^{\circ}$ 9.605, de 12 de fevereiro de 1998, que dispõe sobre as sansões penais e administrativas derivadas de condutas e atividades lesivas ao meio ambiente e dá outras providências. Essa legislação descreve que se o crime tornar uma área, urbana ou rural, imprópria para a ocupação humana devido ao lançamento de resíduos sólidos, líquidos ou gasosos, ou detritos, óleos ou substâncias oleosas, em desacordo com as exigências estabelecidas em leis ou regulamentos, a pena é a reclusão de um a cinco anos [7]. A Resolução CONAMA $n^{0} 357$ é mais específica, pois estabelece os limites de lançamento de efluentes apenas para os recursos hídricos.

Há evidências científicas, na área da saúde, do aumento do risco de câncer, em diferentes órgãos do corpo humano, associados com a utilização de fluidos de corte. Os tipos e quantidade dos constituintes químicos dos fluidos sofrem grande variação podendo conter componentes carcinogênicos, como as $\mathrm{N}$-nitrosaminas. Dentre os diversos tipos de fluido de corte o que tem se revelado mais agressivo à 
saúde do operador é o óleo integral. O fluido de corte aquoso é o menos agressivo, porém, merece atenção devido à sua crescente utilização [8-10].

Dentro desse contexto, este trabalho teve como motivação apresentar um processo ecologicamente correto para o descarte de fluido de corte sintético. 


\section{CAPÍTULO 2:}

\section{OBJETIVOS}

objetivo deste trabalho é avaliar o Processo Fenton no tratamento de
fluidos de corte sintéticos, assim como, estudar a viabilidade do emprego da foto-oxidação. Os Processos Fenton e foto-Fenton serão comparados com o processo de hidrólise ácida, como formas de tratamento de fluidos de corte. 


\section{CAPÍTULO 3:}

\section{REVISÃO BIBLIOGRÁFICA}

\subsection{FLUIDO DE CORTE}

Durante o processo de corte ocorre a geração de calor proveniente do atrito ferramenta/peça e cavaco/ferramenta. Com a utilização de fluidos de corte, pode-se diminuir o coeficiente de atrito reduzindo, assim, a quantidade de calor gerado no processo.

Taylor, em 1890, introduziu a utilização de fluido de corte na usinagem dos materiais [11]. Inicialmente, ele utilizou água para resfriar a região ferramenta/peça/cavaco, conseguindo aumentar a velocidade de corte em $33 \%$. Depois, começou a utilizar água e soda, ou água e sabão para evitar a oxidação da peça e/ou ferramenta. Os óleos minerais surgiram para aplicação na usinagem de latão e, com o desenvolvimento de ferramentas, induziu-se o estudo e geração de novos fluidos de corte, surgindo os óleos emulsionáveis e sintéticos.

As principais funções dos fluidos de corte são lubrificação e refrigeração do corte, mas também outras funções podem ser aplicadas como:

- prevenção contra a soldagem cavaco-ferramenta (formação de arestas postiças);

- retirada do cavaco da região do corte;

- proteção contra a corrosão; 
- redução da dilatação térmica da peça;

- minimização do dano à estrutura superficial e ao crescimento exagerado de tensões residuais na superfície da peça usinada e

- redução no custo, devido a diminuição na compra de ferramentas para usinagem.

Há uma grande variedade de fluidos disponíveis no mercado, que são divididos em quatro classes e agrupados em dois tipos básicos: os fluidos de corte integrais, compreendidos pelos óleos integrais e os fluidos de corte à base de água, composto pelos fluidos emulsionáveis, semi-sintéticos e sintéticos (Figura 1) $[12,13]$

Figura 1: Tipos de fluidos de corte existentes no mercado e suas subdivisões.

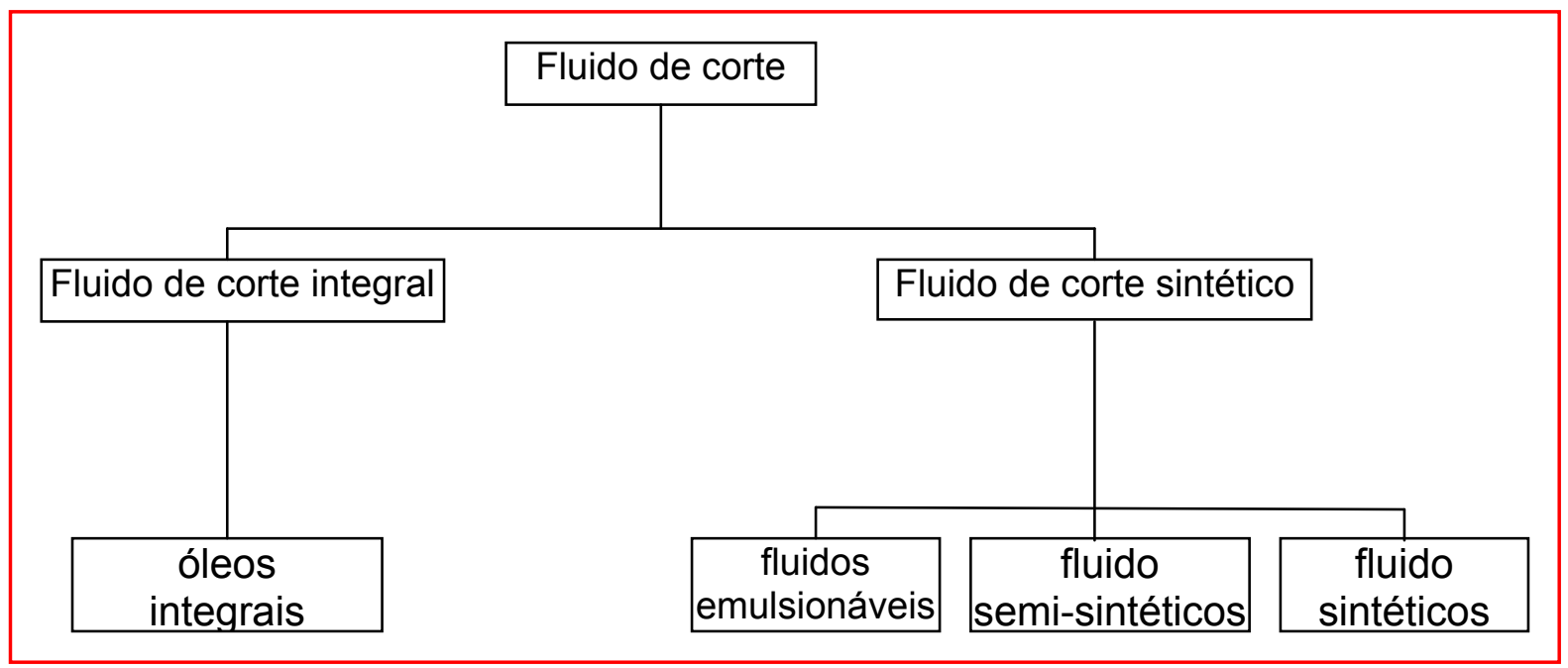

A seguir encontra-se uma breve introdução sobre as classes de fluidos existentes, porém, este trabalho foi realizado com fluido do tipo integral sintético. 


\subsection{TIPOS DE FLUIDOS, COMPOSIÇÃO E PROPRIEDADES}

Os óleos integrais têm como composto básico o óleo mineral, podendo ser utilizados no estado puro (sem aditivação) ou aditivado (presença de aditivos polares e/ou aditivos químicos ativos ou inativos). Os óleos de corte possuem excelentes propriedades lubrificantes, bom controle da ferrugem, vida útil longa, porém apresentam menor poder refrigerante quando comparados com fluidos de corte à base de água [14, 15]. Não são corrosivos e, se mantidos limpos, podem ser usados por longo tempo. O tipo de óleo mineral empregado também é importante, devendo ser usados óleos de base parafínica e com baixo nível de carbonos aromáticos, para não causar danos à saúde do operador.

Nas emulsões, o óleo mineral está disperso na água em forma de minúsculas gotículas, devido à presença de emulgadores e agentes tensoativos que modificam o meio reacional, que permitem solubilizar espécies de baixa solubilidade ou promover um novo meio que possa modificar a velocidade reacional, a posição de equilíbrio das reações químicas e, em alguns casos, a estereoquímica da reação.

Um tensoativo típico possui a estrutura $\mathrm{R}-\mathrm{X}$, onde $\mathrm{R}$ é uma cadeia de hidrocarboneto variando de 8 a 18 átomos (normalmente linear) e X é o grupo cabeça, polar (ou iônico). Dependendo de X, os tensoativos podem ser classificados como não-iônicos, catiônicos, aniônicos ou anfóteros [15, 16].

Os agentes tensoativos reduzem o tamanho das partículas do óleo mineral em minúsculas frações (gotículas), mantendo-as dispersas e evitando a sua coalescência. Necessita-se de cuidados especiais quanto à qualidade da água utilizada, para um efetivo controle de microrganismos (bactérias e fungos), do $\mathrm{pH}$ e da concentração da emulsão. As emulsões apresentam menor poder lubrificante e maior poder refrigerante que o óleo integral $[15,17]$. 
Os óleos semi-sintéticos possuem de 5 a $50 \%$ de óleo mineral mais aditivos e compostos químicos dissolvidos em água formando moléculas individuais ou microemulsões. O óleo mineral emulsionável é adicionado com a finalidade de propiciar uma emulsão estável, translúcida e composta de minúsculas gotículas de óleo. Possuem melhor controle de oxidação que as emulsões convencionais, porém possuem lubrificação insuficiente em determinadas operações, bem como a formação de compostos insolúveis. A menor quantidade de óleo mineral e a presença de biocidas,quando comparados com as emulsões, aumentam a vida útil do fluido e reduzem os riscos à saúde $[15,17]$.

Os fluidos sintéticos são soluções químicas constituídas de sais orgânicos e inorgânicos dissolvidos em água, não contendo óleo mineral. Possuem ótimo poder de refrigeração, excelente poder detergente, melhora da visibilidade na região de corte e elevada resistência à oxidação do fluido. As desvantagens são o baixo poder lubrificante e a formação de compostos insolúveis e de espumas para determinadas operações $[15,17]$

\subsection{TOXICIDADE À SAÚDE E MEIO AMBIENTE}

Atualmente cresce na comunidade industrial a compreensão sobre a necessidade de se considerarem os aspectos ambientais relacionados aos fluidos de corte, obtendo com isso vantagens econômicas e ecológicas. Diversas instituições ocupam-se com o desenvolvimento de tecnologia que possibilite a minimização e eliminação do uso de fluidos de corte nos processos de usinagem [1].

Resíduos de fluidos de corte possuem variações incontáveis na sua composição química e toxicidade e são produzidos em grande quantidade pelas indústrias do setor metal-mecânico. Eles possuem um elevado potencial de poluição 
mesmo em baixas concentrações, portanto seu gerenciamento seguro é um dos pontos determinantes para o desenvolvimento das indústrias metal-mecânicas de forma ambientalmente correta no Brasil [1].

Ainda há uma carência de informações quando se trata de uma análise qualitativa e quantitativa dos impactos ocasionados pela utilização desses produtos. A obtenção de parâmetros como, Demanda Bioquímica de Oxigênio (DBO), Demanda Química de Oxigênio (DQO) e Carbono Orgânico Total (COT), entre outros, é importante no processo de monitoramento de efluentes industriais. Em adição, a determinação dos efeitos tóxicos em organismos aquáticos causados pelo descarte de efluentes industriais é um importante parâmetro em uma avaliação ambiental [1].

Dias et al. realizaram testes de toxicidade aguda com peixes Poecilia reticulata $\left(\mathrm{CL}_{50}\right.$, que é uma indicação da concentração que causa efeito letal em $50 \%$ dos organismos após um determinado período de exposição) e micro crustáceos Daphnia magna ( $\mathrm{CE}_{50}$, que indica a concentração que causa imobilidade a $50 \%$ dos organismos após um determinado período de exposição). Os resultados mostraram que os fluidos de corte são altamente tóxicos, pois baixas concentrações já correspondem à Concentração Letal $\left(\mathrm{CL}_{50}\right)$ para os peixes e também à Concentração Efetiva $\left(\mathrm{CE}_{50}\right)$ para os micro crustáceos [1].

Essa toxicidade em organismos aquáticos pode refletir na saúde do trabalhador exposto durante longo período em contato ao fluido de corte, seja na forma líquida ou no vapor gerado durante o processo de usinagem, acarretando em problemas dermatológicos e respiratórios.

Os problemas dermatológicos são os mais encontrados nos operadores de equipamentos que utilizam fluidos de corte, pois durante a realização da operação 
existem muitas oportunidades de contato do fluido de corte com a pele. Esses efeitos, mais conhecidos no meio médico como dermatites de contato ou ocupacionais, geralmente manifestam-se de duas formas: o contato irritante da derme com o fluido de corte, que pode chegar a umedecer a roupa, ou por reações alérgicas da pele, mesmo quando o contato é de baixa freqüência. A explicação é devida à alcalinidade, que caracteriza a maioria dos fluidos de corte, promovendo a eliminação do efeito protetor das gorduras e dos óleos da pele, facilitando a entrada de microrganismos e partículas nas suas camadas mais profundas. As micropartículas podem penetrar e causar pequenas fissuras na pele, complicando ainda mais o problema dermatológico. A presença de metais como o níquel, cromo ou cobalto podem contribuir para a evolução de feridas [18].

Outro fato relevante, é que as operações de usinagem produzem névoa, fumaça e micropartículas, além de outros gases que podem ser transportados pelo ar e aspirados pelos operadores e funcionários situados próximos ao local de usinagem. Para evitar os riscos envolvidos nesta situação recomenda-se sempre uma avaliação da composição da atmosfera da empresa, limite máximo de 0,5 $\mathrm{mg} / \mathrm{m}^{3}$ para a presença de névoas de fluidos ou partículas estranhas no ar do ambiente e o uso de Equipamentos de Proteção Individuais (EPIs) [8, 18] .

A névoa gerada pelo movimento do fluido que se pulveriza sobre a região onde ocorre a operação de usinagem torna-se irritante para os trabalhadores, principalmente se chegar a casos extremos como o de se visualizar um tom azulado na atmosfera interna da empresa. Nessas condições a concentração atinge valores em torno de 10 a $15 \mathrm{mg} / \mathrm{m}^{3}$, o que indica péssimas condições do ar no local de trabalho [18]. 
O nível de névoa presente no ar está relacionado a fatores tais como: tipo de fluido de corte utilizado, tamanho das gotículas produzidas durante a operação ou, de uma forma mais concreta, ao tipo de usinagem [18]

Precauções especiais devem ser tomadas quando as névoas são constituídas por mesclas de óleos minerais, pois contêm substâncias associadas aos mecanismos de desenvolvimento de câncer no pulmão, em geral, frações de hidrocarbonetos policíclicos aromáticos (HPA), tais como 3,4-benzopireno, antraceno e fenantrenos [18].

Fluidos que apresentam na sua formulação aminas podem reagir com nitratos e nitritos formando as nitrosaminas, que também estão relacionadas ao câncer nos rins, bexiga e fígado. Depois dessa comprovação os fornecedores de fluidos de corte retiraram os nitritos e nitratos da composição do fluido, entretanto é importante ser prudente na aquisição desses produtos.

Acredita-se que os compostos químicos tais como os sulfonatos de benzeno de sódio tetrapropileno e o hidrogênio sulfídrico baixam a resistência imunológica dos trabalhadores, facilitando o surgimento de infecções respiratórias. Para garantir uma atitude preventiva, todas as substâncias mencionadas devem estar dentro de um contexto de gestão através de procedimentos adequados e controle ambiental que integre todas as fases do ciclo de vida do fluido de corte na empresa até a sua reutilização, descarte ou disposição final, contribuindo, assim, para a contínua melhoria ambiental [18].

\subsection{RECUPERAÇÃO E TRATAMENTOS}

Dados da literatura mostram que existem processos, não de tratamento, mas de purificação dos fluidos de corte, que apenas retiram da solução a fase sólida 
presente. A filtração será usada como ferramenta para separar as partículas sólidas presentes na solução e não será avaliada a utilização desse procedimento. Os fluidos de corte são normalmente submetidos a processos de purificação, através de sistemas individuais ou centralizados (para várias máquinas). Tratam-se os fluidos, tendo como objetivos:

- redução da mão-de-obra na limpeza de reservatórios;

- controle das propriedades dos fluidos, para que sejam garantidas as concentrações corretas para cada máquina (nos sistemas centralizados);

- redução do descarte com possibilidade de remoção de metálicos finos, resíduos de rebolo e outros contaminantes;

- melhoria da qualidade das peças fabricadas e

- aumento da vida útil do fluido de corte.

Esses métodos de purificação não são utilizados somente com o intuito de prolongar a vida útil do fluido de corte, mas também para retirar a parte sólida que constitui o fluido no momento de seu tratamento e/ou disposição. Abaixo estão citados dois métodos mais utilizados para a separação da fração sólida contida nos resíduos de fluido de corte.

O primeiro é a decantação, ou seja, separação por gravidade. Usualmente, existem dispositivos auxiliares como barras raspadoras, planos inclinados etc., com o objetivo da melhoraria no desempenho dessa operação. Existem, também, dispositivos especiais para a decantação que desempenham a mesma função de separação. Estes sistemas, chamados de separadores, são geralmente usados em conjunto com a decantação aumentando a eficiência do processo de purificação. 
O segundo método é a filtração, que consiste no uso de meios porosos por onde passa o fluido de corte. A passagem pode ser promovida por gravidade, sucção ou pressão.

O fluido de corte estudado nesta pesquisa é do tipo sintético à base de "polialquileno glicol", fornecido pelo Núcleo de Manufatura Avançada - NUMA da Escola de Engenharia de São Carlos - EESC-USP. O NUMA, como um centro de pesquisa, preocupa-se com o destino adequado dos resíduos de fluidos de corte e está como parceiro na realização deste trabalho.

A literatura escassa relacionada ao descarte de fluidos de corte utilizados em indústrias metal-mecânicas limitou uma extensa revisão sobre o assunto.

\subsection{DESCARTE DE FLUIDO DE CORTE INTEGRAL}

Os fluidos de corte integrais, quando mantidos livres de contaminantes, podem ser utilizados indefinidamente. Porém, o acúmulo de contaminação provoca a rápida deterioração dos aditivos e das propriedades dos fluidos integrais, contribuindo para abreviar a vida útil do fluido de corte. Embora inadequados à utilização para a qual foram originalmente fabricados, eles podem ser aproveitados em operações de lubrificação de menor exigência [18].

Os fluidos de corte integral podem ser vendidos para novo refinamento ou podem ser recuperados pelo próprio usuário, pelo fabricante do fluido ou por uma companhia especializada [12].

Em geral, nas reciclagens dos fluidos integrais retiram-se os contaminantes e substitui-se algum aditivo que se degradou e o fluido recuperado pode, então, voltar ao uso [18]. 
Quando for inviável a reciclagem e a reutilização, o fluido pode ainda servir de combustível, desde que o forno e o fluido atendam às exigências da legislação específica para a queima de compostos contendo hidrocarbonetos [18].

\subsection{DESCARTE DE FLUIDOS DE CORTE À BASE DE ÁGUA}

Os fluidos sintéticos ou soluções são constituídos de gama de produtos químicos. A maioria destes fluidos caracteriza-se pelas seguintes propriedades: alcalinidade (pH entre 7,8 e 10,2); elevadas cargas orgânicas, constituídas de cadeias lineares e de fácil degradação por bactérias inoculadas e por oxidação química.

Muitos produtos químicos utilizados na composição dos fluidos de corte, como biocidas, anticorrosivos, umectantes, flavorizantes, antiespumantes e outros aditivos, podem ter efeitos nocivos sobre o homem e a natureza. Com a evolução tecnológica, uma grande quantidade de novos produtos sintéticos são lançados no mercado para os quais não existem testes toxicológicos adequados e, como é complexa a tarefa de monitorá-los, os órgãos ambientais recomendam atitudes preventivas [12].

A OSHA (Occupation Safety and Health Administration) regulamentou algumas substâncias a serem observadas nas formulações de fluidos de corte, entre elas estão: etanolamina, dietanolamina, hexileno glicol, morfolina, p-cloro-m-cresol, policlorados alcalinos de $\mathrm{C}_{10}$ a $\mathrm{C}_{13}$, nitrodietanolamina, o-fenilfenol, éter de Glicol, solvente de Stoddard, nitritos, óleos de cadeias polinucleares aromáticas (PNA), óleo parafínicos clorados de cadeias curtas, compostos de bário, névoa de óleo e compostos de cobre [19]. 
Um fluido que contenha qualquer um destes compostos não pode ser considerado "limpo", apesar de que nenhum efeito específico possa ser comprovadamente e diretamente ligado ao uso de tais substâncias. Entretanto, alguns efeitos nocivos foram associados a tais componentes, assim, o recomendável é a precaução [12].

As emulsões e soluções não podem ser simplesmente descartadas no sistema de esgoto, havendo a necessidade de separar o óleo da água (no caso de emulsões) com posterior tratamento da fase aquosa.

A hidrólise ácida (Método Químico) consiste na adição de ácidos para abaixar $\mathrm{opH}$ e de sais metálicos (sulfato de alumínio, cloreto de ferro ou sulfato ferroso) para formar sabões insolúveis, levando à quebra da emulsão. A fase aquosa resultante da separação do óleo contém metais provenientes da manufatura da peça, desta forma deve-se precipitá-los. Após sua neutralização, o efluete deve estar de acordo com a legislação vigente para seu descarte. A fase oleosa separada é removida, sendo tratada como fluido integral. O resíduo sólido, depois de caracterizado, é enviado para aterro industrial. Os resíduos do óleo poderão ser retirados por meios mecânicos ou absorvidos por hidróxidos metálicos ou sílica [12].

A quebra química de emulsões somente é bem sucedida quando os compostos são íon-ativos. [18].

A quebra da emulsão pode ser feita também pelo aquecimento da mistura (Método Térmico) onde a água evapora, separando-se do óleo. A vantagem deste processo é de não utilizar compostos químicos para realizar a quebra da emulsão, facilitando o tratamento final dos resíduos; no entanto é necessário maior dispêndio de energia para provocar a evaporação da água [18]. 
Os métodos biológicos ainda são pouco utilizados como alternativa de tratamento de fluidos de corte, pois sua principal limitação está na quantidade de biocidas presentes nos fluidos. O princípio básico do seu funcionamento é o desenvolvimento de microorganismos que eliminam os resíduos indesejáveis [18].

Observando a complexidade para o gerenciamento dos resíduos de fluidos de corte, conclui-se que é necessária uma metodologia eficiente para se realizar uma manipulação responsável dos fluidos de corte a fim de reduzir seus resíduos e garantir um ambiente seguro e sem riscos à saúde do trabalhador e da população. A gestão dos problemas provocados pelo uso dos fluidos de corte gera custos, mas seu resultado leva à melhora do controle e à manutenção dos fluidos, possibilitando uma melhor qualidade ambiental [18].

\subsection{PROCESSOS OXIDATIVOS AVANÇADOS}

O desenvolvimento de alternativas de baixo custo, de fácil implementação e operação, efetivamente eficientes para a remoção da carga orgânica presente nos resíduos de fluido de corte é premente.

Em sua maioria, a poluição encontrada em águas residuais é proveniente das atividades humanas. No geral, a remoção de poluentes orgânicos envolve uma ou mais técnicas básicas, entre elas a oxidação química, aeração, extração líquidolíquido, adsorção, osmose, ultrafiltração e biodegradação [20].

A escolha de um ou outro método depende do balanço geral que envolve o custo do processo e fatores como a concentração e volume do efluente. Dentre essas técnicas, os processos de oxidação avançados (POAs) vêm se mostrando como um dos mais adequados para a degradação de poluentes aquosos [20, 21]. 
Os processos oxidativos avançados são aqueles em que radical hidroxila $(\cdot \mathrm{OH})$ participa como principal agente oxidante. Trata-se de uma espécie de elevado poder oxidante $\left(E^{\circ}=2,06 \mathrm{~V}\right)$, que permite a completa mineralização de inúmeras espécies químicas de relevância ambiental, em tempo relativamente curto [22].

Os POAs são caracterizados por sua capacidade de oxidação total ou parcial, resultando, neste último caso, em um decréscimo do material orgânico e/ou aumento da biodegradabilidade [23].

Os POAs apresentam uma série de vantagens, podendo-se citar:

- mineralizam o poluente e não somente transferem-no de fase;

- são muito usados para compostos de difícil degradação sob outros tratamentos;

- transformam produtos refratários em compostos biodegradáveis;

- podem ser utilizados em conjunto com outros processos (pré e pós tratamento);

- têm forte poder oxidante, com cinética de reação elevada;

- geralmente não necessitam um pós-tratamento e disposição final;

- tendo sido utilizada uma quantidade de oxidante suficiente, eles mineralizam o contaminante e não formam subprodutos;

- geralmente melhoram a qualidade organoléptica da água tratada;

- em muitos casos, consomem menos energia, acarretando menor custo;

- possibilitam o tratamento in situ [24].

Dentre todos os possíveis agentes oxidantes disponíveis no mercado, o peróxido de hidrogênio foi o escolhido para os testes devido ao baixo custo e alto poder de oxidação como mostrado na Tabela 1, além de ser facilmente manuseado, ter boa solubilidade em água e não formar produtos secundários [20]. 
$\mathrm{O} \mathrm{H}_{2} \mathrm{O}_{2}$ sozinho não é eficiente para a oxidação de certos contaminantes de difícil degradação, como compostos aromáticos clorados e compostos inorgânicos (como cianetos), devido às baixas taxas de reação em concentrações razoáveis de $\mathrm{H}_{2} \mathrm{O}_{2}$. Sais de metais de transição (como sais de ferro), ozônio e luz ultravioleta podem ativar o peróxido de hidrogênio para formar radicais hidroxila [25].

Tabela 1: Poder de oxidação de espécies reativas em relação ao cloro [20].

\begin{tabular}{|l|c|}
\hline \multicolumn{1}{|c|}{ Espécie Reativa } & $\begin{array}{c}\text { Poder Relativo } \\
\text { de Oxidação } \\
\left(\mathbf{C l}_{\mathbf{2}} \mathbf{= 0}\right)\end{array}$ \\
\hline Fluoreto & 2,23 \\
Radical Hidroxila & 2,06 \\
Oxigênio Atômico & 1,78 \\
Peróxido de Hidrogênio & 1,25 \\
Radical Peridróxido & 1,24 \\
Permanganato & 1,17 \\
Ácido Hipobromoso & 1,15 \\
Dióxido de cloro & 1,10 \\
Ácido Hipocloroso & 1,07 \\
Ácido Hipoiodoso & 1,00 \\
Bromo & 0,54 \\
\hline
\end{tabular}

Em função da sua elevada reatividade, o radical hidroxila deve ser produzido in situ. Dentre as principais formas de produção encontram-se:

\section{a) Sistema Fenton}

O sistema consiste na geração de radical hidroxila a partir de uma mistura de peróxido de hidrogênio e sais ferrosos.

$$
\mathrm{Fe}^{+2}+\mathrm{H}_{2} \mathrm{O}_{2} \rightarrow \mathrm{Fe}^{+3}+\mathrm{OH}^{-}+\cdot \mathrm{OH}
$$


As limitações de $\mathrm{pH}$ e a formação de precipitados coloidais de hidróxido férrico representam as maiores dificuldades de aplicação do método.

O processo Fenton pode ser associado à irradiação UV-B (280 a $320 \mathrm{~nm})$, UV-A (320 a $400 \mathrm{~nm}$ ) e Vis (400 a $800 \mathrm{~nm}$ ), sendo denominado sistema foto-Fenton. Com a presença de radiação, ocorre a regeneração das espécies $\mathrm{Fe}^{+2}$ fechando o ciclo catalítico, produzindo dois radicais hidroxila para cada mol de $\mathrm{H}_{2} \mathrm{O}_{2}$ decomposto inicialmente [20].

$$
\mathrm{Fe}^{+3}+\mathrm{H}_{2} \mathrm{O}+\mathrm{h} v \rightarrow \mathrm{Fe}^{+2}+\mathrm{H}^{+}+\cdot \mathrm{OH}
$$

\section{b) Sistema foto-Fenton}

O processo foto-Fenton é um dos Processos Oxidativos Avançados mais estudados. No seu mecanismo clássico, radicais hidroxilas são formados pela reaçõe de oxidação e redução de íons $\mathrm{Fe}^{2+}$ na presença de peróxido de hidrogênio e radiação UV. Na primeira etapa, os íons ferrosos são oxidados pelo $\mathrm{H}_{2} \mathrm{O}_{2}$ (Reação de Fenton), gerando radicais hidroxila (eq 3). Na segunda etapa, os íons férricos $\left(\mathrm{Fe}^{3+}\right)$ são reduzidos fotoquimicamente para o estado de oxidação inicial $\left(\mathrm{Fe}^{2+}\right)$, (eq. 4), que reage novamente com peróxido de hidrogênio gerando mais radicais hidroxila $[26,27]$.

$$
\begin{aligned}
& \mathrm{Fe}^{2+}+\mathrm{H}_{2} \mathrm{O}_{2} \rightarrow \mathrm{Fe}^{3+}+\mathrm{OH}^{\cdot} \\
& \mathrm{Fe}^{3+}+\mathrm{H}_{2} \mathrm{O}+h_{\bullet} v \rightarrow \mathrm{Fe}^{2+}+\mathrm{H}^{+}+\mathrm{OH}^{-}
\end{aligned}
$$




\section{c) Fotocatálise Heterogênea}

O processo fotocatalítico fundamenta-se na geração de pares elétrons-lacuna $\left(\mathrm{e}^{-}\right.$ $/ \mathrm{h}^{+}$), quando materiais semicondutores são iluminados com radiação de energia maior ou igual à do seu band gap, conforme mostra a Figura 2. Este conjunto representa sítios reativos com capacidade para reduzir ou oxidar substratos de interesse. No entanto, admite-se que a principal via de reação é mediada por radical hidroxila, que surge da reação entre a lacuna foto gerada e moléculas de água (ou $\mathrm{OH}^{-}$), previamente dessorvidas na superfície do semicondutor [21].

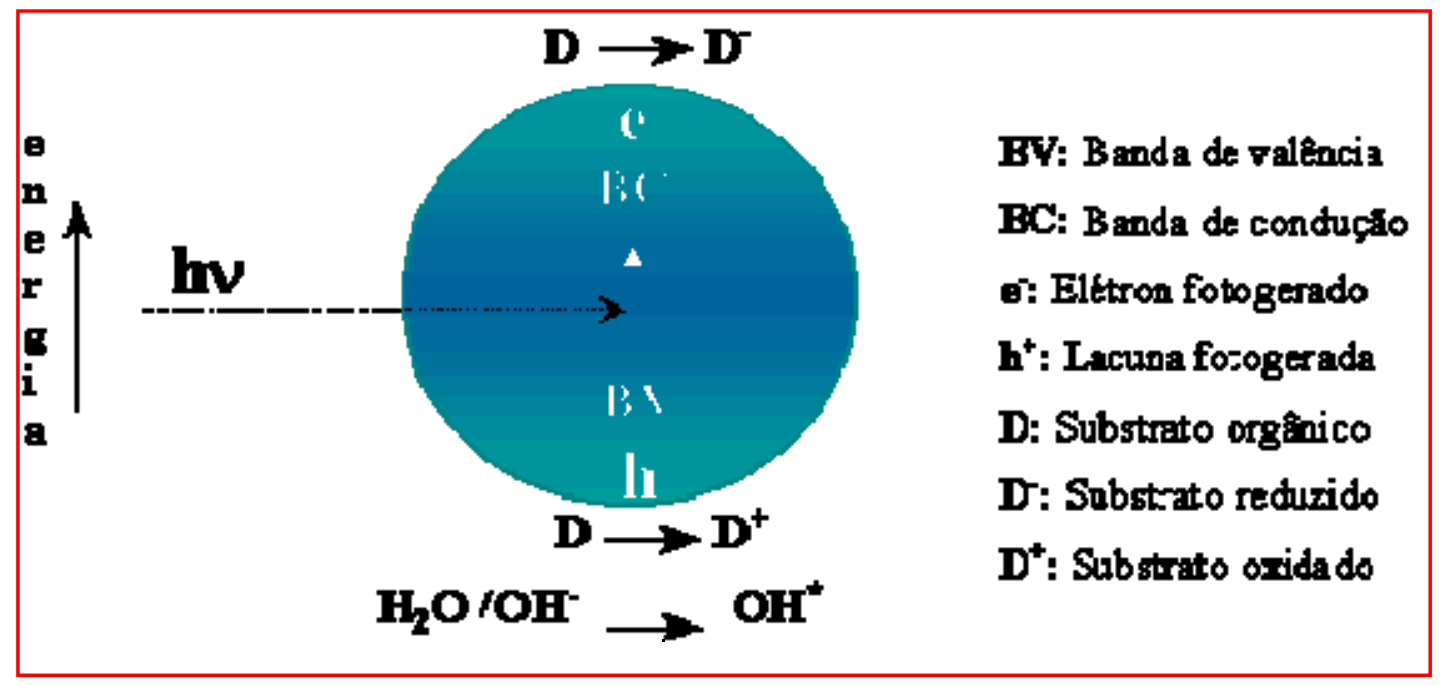

Figura 2: Band gap [21].

\section{d) Sistemas Ozonizados}

O ozônio, a forma tri-atômica do oxigênio, apresenta-se como um gás incolor e de odor pungente. Em fase aquosa, o ozônio decompõe-se rapidamente a oxigênio e espécies radicalares. É um agente oxidante poderoso $\left(E^{\circ}=2,08 \mathrm{~V}\right)$ quando comparado a outros agentes oxidantes, como por exemplo, $\mathrm{H}_{2} \mathrm{O}_{2}\left(E^{\circ}=1,78\right.$ V), permitindo que esta espécie possa reagir com uma numerosa classe de compostos [21]. 
Os processos que utilizam ozônio têm sido muito estudados para o tratamento de efluentes industriais e águas potáveis, uma vez que este tratamento, além de destruir as moléculas de contaminantes, possui um alto poder de desinfecção, sendo também capazes de eliminar os microorganismos patogênicos presentes. Nesses processos os radicais hidroxila são gerados pela decomposição do $\mathrm{H}_{2} \mathrm{O}_{2}$ via fotólise do ozônio [6].

Os processos mais comuns de ozonização são a ozonização catalítica e o sistema ozônio/ $\mathrm{H}_{2} \mathrm{O}_{2}$.

No processo de ozonização catalítica ocorre a ativação do ozônio pelos metais presentes no efluente (catálise heterogênea). Várias espécies metálicas (ferro, manganês, níquel, cobalto, zinco, prata e cromo) em suas diversas formas (sal, metal reduzido, óxido sólido, metal depositado em suporte) são relatados, como agentes intensificadores da eficiência da ozonização de águas residuárias [21].

No sistema ozônio/ $\mathrm{H}_{2} \mathrm{O}_{2}$ o radical hidroxila é gerado através de um mecanismo de cadeia radicalar devido à interação entre ozônio e peróxido de hidrogênio. A eficiência deste processo pode ser ampliada com a adição de radiação ultravioleta [21].

A reação global pode ser representada pela equação:

$$
\begin{gathered}
\mathbf{O}_{3}+\mathbf{H}_{\mathbf{2}} \mathbf{O} \stackrel{h v}{\longrightarrow} \mathbf{H}_{\mathbf{2}} \mathbf{O}_{2}+\mathbf{O}_{\mathbf{2}} \\
\mathbf{H}_{\mathbf{2}} \mathbf{O}_{2} \stackrel{h v}{\longrightarrow} \mathbf{2} \cdot \mathbf{O H}
\end{gathered}
$$

\subsubsection{SISTEMA FENTON}

Fenton relatou há mais de um século a oxidação catalítica de ácido tartárico na presença de sais ferrosos e peróxido de hidrogênio. Quarenta anos após a 
primeira observação do que seria a chamada "reação de Fenton", foi proposto que o radical hidroxila é a espécie oxidante neste sistema, capaz de oxidar várias classes de compostos orgânicos em uma reação espontânea [25, 28].

A reação entre os íons ferrosos e o peróxido de hidrogênio resulta na formação de radicais e íons férricos (Reação de Fenton), como descrito na equação 1. Os íons férricos reagem com o peróxido de hidrogênio, gerando um complexo no qual os íons ferrosos são formados novamente (eq. 2). Esta regeneração natural é característica do Reagente de Fenton [23, 25].

$$
\begin{gathered}
\mathrm{Fe}^{+2}+\mathrm{H}_{2} \mathrm{O}_{2} \rightarrow \mathrm{Fe}^{+3}+\mathrm{OH}^{-}+\cdot \mathrm{OH} \\
\mathrm{Fe}(\mathrm{III})+\mathrm{H}_{2} \mathrm{O}_{2} \rightarrow\left(\mathrm{Fe} \ldots \mathrm{O}_{2} \mathrm{H}\right)^{+2}+\mathrm{H}^{+} \\
\left(\mathrm{Fe} . . \mathrm{O}_{2} \mathrm{H}\right)^{+2} \rightarrow \mathrm{Fe}(\mathrm{II})+\mathrm{HO}_{2} \cdot
\end{gathered}
$$

Por outro lado, os radicais hidroxila formados na primeira etapa também reagem com peróxido de hidrogênio gerando radicais peridróxido [23].

$$
\cdot \mathrm{OH}+\mathrm{H}_{2} \mathrm{O}_{2} \rightarrow \mathrm{HO}_{2}+\mathrm{H}_{2} \mathrm{O}
$$

Estes radicais podem reagir com os íons férricos presentes na reação média:

$$
\mathrm{HO}_{2}+\mathrm{Fe}(\mathrm{III}) \rightarrow \mathrm{Fe}(\mathrm{II})+\mathrm{H}^{+}+\mathrm{O}_{2}
$$

Devido aos radicais hidroxila serem mais seletivos que os peridróxidos com compostos orgânicos, é assumido que o radical hidroxila é o responsável pela oxidação de poluentes orgânicos, dessa forma: 
Porém, esta reação deve obedecer a alguns fatores que são determinantes para um bom rendimento ou mesmo para que a reação ocorra. Desta forma a reação deve ocorrer sob certas condições que são discutidas no item 3.4.3 [23].

\subsubsection{SISTEMA FOTO-FENTON}

A radiação UV, com comprimentos de onda de 6 a $400 \mathrm{~nm}$, divide-se em ultravioleta próximo, distante e no vácuo. A energia gerada por essa radiação é suficiente para a remoção de elétrons da camada de valência e, conseqüentemente, capaz de romper algumas ligações químicas. Apesar de a radiação UV conseguir gerar radicais oxidantes, em muitos casos, principalmente quando o composto não sofre fotólise direta, ou essa é muito pequena, o uso combinado com outros agentes oxidantes propicia um aumento de eficiência [29].

A capacidade de degradação do processo Fenton pode ser sensivelmente aumentada quando este é fotoassistido. Esse incremento é conseguido com a aplicação de radiação tanto na região espectral que compreende o ultravioleta como o visível. A excitação proporcionada pela radiação permite a transferência de um elétron da água para o íon férrico, regenerando-o a íon ferroso, e gerando um radical hidroxila (eq. 13). Os íons ferrosos regenerados podem por sua vez reagir novamente com $\mathrm{H}_{2} \mathrm{O}_{2}$ [30].

A combinação de peróxido de hidrogênio e íons $\mathrm{Fe}^{2+}$ ou $\mathrm{Fe}^{3+}$ com radiação ultravioleta (UV), denominado processo foto-Fenton, produz mais radicais hidroxilas quando comparado ao método Fenton convencional $\left(\mathrm{Fe}^{2+} \mathrm{com} \mathrm{H}_{2} \mathrm{O}_{2}\right)$ ou à simples 
fotólise, aumentando a eficiência na degradação de poluentes orgânicos, atribuída principalmente à foto-redução de $\mathrm{Fe}^{3+}$ para $\mathrm{Fe}^{2+}[29]$.

$$
\begin{gathered}
\mathrm{FeOH}^{2+}+\mathrm{hv} \rightarrow \mathrm{Fe}^{2+}+\mathrm{HO} . \\
\mathrm{Fe}^{3+}+\mathrm{H}_{2} \mathrm{O} \stackrel{h v}{\longrightarrow} \mathrm{Fe}^{2+}+\cdot \mathrm{OH}+\mathrm{H}^{+}
\end{gathered}
$$

Durante a reação, ocorre também a formação de outros compostos intermediários: estados excitados da matéria orgânica dissolvida, peróxido de hidrogênio, oxigênio singlete, elétron hidratado, íons superóxidos, radicais organoperóxidos, radicais hidroxila e radicais halogênios. A formação desses radicais é o ponto chave do procedimento, melhorando a eficiência na decomposição.

O mecanismo que envolve o processo foto-Fenton é formado por inúmeras reações elementares com diversos radicais e formação de complexos de ferro com a água, compostos orgânicos intermediários do processo e outros interferentes. O ferro III em estado sólido não sofre fotólise, vários autores sugerem que o ferro III forma complexos em meio aquoso, dessa forma temos [6, 28, 31, 32]:

$$
\begin{gathered}
\mathrm{Fe}^{3+}+\mathrm{H}_{2} \mathrm{O} \leftrightarrow \mathrm{Fe}(\mathrm{OH})^{2+}+\mathrm{H}^{+} \\
\mathrm{Fe}^{3+}+2 \mathrm{H}_{2} \mathrm{O} \leftrightarrow \mathrm{Fe}(\mathrm{OH})_{2}^{+}+2 \mathrm{H}^{+}
\end{gathered}
$$

Estes compostos por sua vez sofrem fotólise, gerando radicais hidroxila e íons ferrosos: 


$$
\begin{gathered}
\mathrm{Fe}(\mathrm{OH})_{2}^{+}+\mathrm{h} v \rightarrow \mathrm{Fe}(\mathrm{OH})^{+}+\cdot \mathrm{OH} \\
\mathrm{Fe}(\mathrm{OH})_{2}^{+}+\mathrm{h} v \rightarrow \mathrm{Fe}^{2+}+\cdot \mathrm{OH}
\end{gathered}
$$

Outras reações de menor destaque participam do processo, promovendo a redução de ferro III a ferro II, gerando radicais hidroperóxido e oxigênio molecular [6, $28,31]$

$$
\begin{gathered}
\mathrm{FeOOH}^{2+} \rightarrow \mathrm{Fe}^{2+}+\mathrm{HOO} \\
\mathrm{FeOOH}^{2+}+\mathrm{FeOH}^{2+} \rightarrow \mathrm{Fe}^{2+}+\mathrm{O}_{2}^{+}+\mathrm{H}_{2} \mathrm{O}
\end{gathered}
$$

Os radicais hidroxiperóxido, além de atacarem a substância orgânica, também reduzem o íons férrico a íons ferroso $[6,28]$.

$$
\mathrm{FeCOOH}^{2+}+\mathrm{h} v \rightarrow \mathrm{Fe}^{2+} \mathrm{CO}_{2}+\mathrm{H}^{+}
$$

As seguintes suposições podem ser consideradas verdadeiras no processo de fotodegradação:

(i) a aproximação para estado estacionário pode ser aplicada para radicais altamente reativos, tais $\mathrm{como} \cdot \mathrm{OH}$ e $\mathrm{HO}_{2} \cdot$;

(ii) as reações de terminação radical-radical têm velocidades semelhantes às velocidades das reações de propagação;

(iii) a concentração do íon ferroso é mantida constante durante o tempo de reação e

(iv) a concentração de oxigênio está sempre em excesso [6]. 


\subsubsection{FATORES QUE INTERFEREM NA REAÇÃO}

\section{a) $\mathrm{pH}$ inicial}

$\mathrm{O}$ pH inicial tem uma significante importância na oxidação de compostos orgânicos, sendo que nos Sistemas Fenton e foto-Fenton a influência é muito mais crucial, pois estes sistemas são baseados na especiação de $\mathrm{Fe}(\mathrm{II})$ usado na catálise da reação.

É observado que trabalhando em um intervalo de $\mathrm{pH}$ entre 2,5 e 3,5 a redução do substrato é rápida, sendo em pH 3 a condição ideal para a reação[23].

Esta variação na taxa de velocidade é justificada devido ao $\mathrm{Fe}(\mathrm{OH})^{+2}$ ser o responsável pela geração de radicais hidroxila e não o ferro(III). Ao analisar um diagrama de especiação dos íons ferro pode-se observar que a $\mathrm{pH} 3$ temos uma concentração predominante de $\mathrm{Fe}(\mathrm{OH})^{+2}$, abaixo deste $\mathrm{pH}$ e acima de $\mathrm{pH} 5$ teremos um aumento na concentração de $\mathrm{Fe}(\mathrm{III})$ o que não é favorável para a reação [23, 33].

Esta estreita faixa de $\mathrm{pH}$ em que é máxima a eficiência da reação de Fenton e foto-Fenton é uma das grandes limitações do processo, pois há a necessidade de ajuste de $\mathrm{pH}$ para máxima eficiência do tratamento, além da necessidade de neutralização após tratamento antes do descarte em corpos d’água [28].

\section{b) Concentração de íons ferro}

Não há evidencias da formação de radicais hidroxilas sem a presença de íons $\mathrm{Fe}^{2+}$. Quando a concentração de ferro é aumentada, a taxa de remoção do substrato aumenta até alcançar um valor onde a adição de mais íons ferro não altera a velocidade da reação [23]. 
No entanto, um fator que deve ser considerado consistente no fato de que um excesso de íons $\mathrm{Fé}^{+2}$ pode haver prejuízo na eficiência do processo devido à ocorrência de reações entre essa espécie com alguns radicais intermediários, como o radical $\cdot \mathrm{OH}$, provocando uma competição pelos radicais hidroxila entre os reagentes utilizados e o composto orgânico a ser degradado [34].

De acordo com Kolthoff et al, deve ser observado dois fatores quanto à concentração de íons ferro na solução: a concentração mínima deve ser de 3-15 mg/L para a reação proceder em um período de tempo razoável e a razão entre Fe:substrato deve ser de no mínimo 1 parte de Fe para 10-50 partes de substrato para que ocorra o produto final desejado [35].

\section{c) Tipo de íos ferro}

Para a maioria das aplicações, não há problema em se usar sais de $\mathrm{Fe}^{+2}$ ou $\mathrm{Fe}^{+3}$ para catalisar a reação, pois o ciclo catalítico começa rapidamente se a água oxigenada e os materiais orgânicos estiverem em abundância. Porém se baixas doses de Reagente de Fenton ou foto-Fenton forem usadas algumas pesquisas sugerem sais ferrosos [35].

\section{d) Concentração de peróxido de hidrogênio}

Como os radicais hidroxilas possuem um alto poder de oxidação de compostos orgânicos é importante encaminhar uma reação em laboratório para cada substrato a ser tratado, pois pode ocorrer a formação de produtos intermediários não desejados entre o substrato e o produto final de reação esperado [35].

$\mathrm{O}$ efeito negativo observado com o aumento do número de moles de $\mathrm{H}_{2} \mathrm{O}_{2}$ pode ser explicado pela adição de excesso de oxidante, provocando uma reação 
entre o peróxido de hidrogênio em excesso com os radicais hidroxilas livres [33, 34], através da equação:

$$
\mathrm{H}_{2} \mathrm{O}_{2}+\cdot \mathrm{OH} \rightarrow \cdot \mathrm{O}_{2} \mathrm{H}+\mathrm{H}_{2} \mathrm{O}
$$

Como resultado, o radical hidroperoxila $\left(\cdot \mathrm{O}_{2} \mathrm{H}\right)$, pode ser produzido. Esses radicais são muito menos reativos que os radicais hidroxila $(\cdot \mathrm{OH})$ e parecem não contribuir para a degradação oxidativa dos compostos orgânicos. Além disso, podem ocorrer reações em série de consumo de radicais que eventualmente reduzem a capacidade oxidativa [33, 34], de acordo com a reação:

$$
\cdot \mathrm{O}_{2} \mathrm{H}+\cdot \cdot \mathrm{OH} \rightarrow \mathrm{H}_{2} \mathrm{O}+\mathrm{O}_{2}
$$

\section{e) Temperatura}

É verificado que a taxa de oxidação aumenta com o aumento da temperatura, com efeitos mais pronunciados a temperaturas abaixo de $20^{\circ} \mathrm{C}$. Entretanto a temperaturas acima de $40-50^{\circ} \mathrm{C}$ a eficiência da água oxigenada diminui, pois sua taxa de decomposição em oxigênio e água aumenta [35].

\section{f) Tempo de Reação}

O tempo necessário para se completar a reação dependerá de muitas das variáveis discutidas acima, mas notavelmente mais da dose catalítica e da concentração de água residuárias [35]. 


\section{CAPÍTULO 4: \\ MÉTODOS DE \\ CARACTERIZAÇÃO}

\subsection{CARBONO ORGÂNICO TOTAL (COT)}

O carbono orgânico em águas e águas residuárias é constituído de uma variedade de compostos orgânicos em vários estados de oxidação. Alguns desses compostos de carbono podem ser oxidados por processos biológicos ou químicos, e os métodos de Demanda Bioquímica de Oxigênio (DBO), Carbono Orgânico Assimilável (COA) e Demanda Química de Oxigênio (DQO) podem ser usados para caracterizar essas frações. O Carbono Orgânico Total (COT) é o mais conveniente e direto para expressar o conteúdo orgânico total que o DBO, DQO ou COA, mas não fornece os mesmos tipos de informações. Se uma relação empírica for estabelecida entre o COT e DBO, DQO, COA para uma específica fonte de água, então o COT pode ser usado para estimar o acompanhamento desses parâmetros. Esta relação pode ser estabelecida independentemente para cada condição fixada da matriz, como vários pontos no processo de tratamento. Diferentemente do DBO e DQO, o TOC é independente do estado de oxidação da matéria orgânica e não mede outros elementos ligados a compostos orgânicos, como nitrogênio e hidrogênio, e 
inorgânicos que podem contribuir para a demanda de oxigênio nas determinações de DBO e DQO.

Para determinar a quantidade de carbono organicamente ligado, as moléculas orgânicas devem ser quebradas e convertidas a forma molecular simples que pode ser medida quantitativamente. Os métodos de COT utilizam altas temperaturas, catalisadores e oxigênio, ou baixas temperaturas $\left(<100^{\circ} \mathrm{C}\right)$ com irradiação ultravioleta, oxidantes químicos ou uma combinação desses oxidantes para converter o carbono orgânico a dióxido de carbono $\left(\mathrm{CO}_{2}\right) \cdot \mathrm{O} \mathrm{CO}_{2}$ pode ser purgado da amostra, seco e transferido por um gás de arraste a um analisador por infravermelho não dispersivo. Alternativamente, ele pode ser separado da fase líquida por uma membrana seletiva de $\mathrm{CO}_{2}$, possuindo água ultra-pura em que um aumento na condutividade corresponde à passagem de $\mathrm{CO}_{2}$ pela membrana [36] .

A determinação do COT foi realizada por leitura direta, sendo necessário apenas filtrar e diluir a solução (1:100 v:v), em um Analisador de Carbono Orgânico Total da marca Shimadzu modelo TOC-V $\mathrm{CPH}_{\mathrm{C}}$. A curva de calibração foi construída utilizando o padrão primário biftalato ácido de potássio.

\subsection{DEMANDA QUÍMICA DE OXIGENIO (DQO)}

A Demanda Química de Oxigênio (DQO) é definida como a quantidade de um oxidante específico que reage com a amostra sob condições controladas. A quantidade de oxidante consumido é expresso em termos da equivalência em oxigênio. Devido a suas propriedades químicas únicas, o íon dicromato $\left(\mathrm{Cr}_{2} \mathrm{O}_{7}{ }^{2-}\right)$ é o oxidante específico para a maioria dos métodos, onde é reduzido a íons crômicos $\left(\mathrm{Cr}^{3+}\right)$. Ambos os componentes orgânicos e inorgânicos da amostra estão sujeitos à oxidação, em muitos casos o componente orgânico predomina e é de grande 
interesse. A extensão da oxidação da amostra pode ser afetada pelo tempo de digestão, pureza dos reagentes e concentração do DQO da amostra [36].

O DQO foi realizado utilizando-se o método titulométrico, inicialmente em um balão de fundo chato adiciona-se $20 \mathrm{~mL}$ da amostra, ou uma porção diluída a $20 \mathrm{~mL}$, aproximadamente $0,4 \mathrm{~g}$ de sulfato de mercúrio e $10 \mathrm{~mL}$ de solução de dicromato de potássio (dissolveu-se 12,259 g de dicromato de potássio em 1 litro de água destilada). Cuidadosamente, acrescentou-se $30 \mathrm{~mL}$ de ácido sulfúrico-sulfato de prata (10,13 g de sulfato de prata em 1 litro de ácido sulfúrico concentrado), sempre agitando o balão. Fez-se um branco, utilizando ao invés da amostra, $20 \mathrm{ml}$ de água destilada. Os balões seguiram para chapas aquecedoras, conectando-os aos condensadores. A solução ficou em refluxo por 2 horas a partir do início da fervura. Depois de completada as 2 horas, e com o SFA (dissolveu-se $98 \mathrm{~g}$ de sulfato ferroso amoniacal (SFA), $20 \mathrm{ml}$ de ácido sulfúrico concentrado, deixar esfriar e completar o volume para 1 litro) já padronizado, realiza-se a titulação da amostra e do branco usando ferroína como indicador. O ponto final é a mudança de cor de azulesverdeado para marrom-avermelhado.

\subsection{DEMANDA BIOQUÍMICA DE OXIGÊNIO (DBO)}

A determinação da Demanda Bioquímica de Oxigênio (DBO) é um teste empírico onde procedimentos de laboratórios padrão são usados para determinar o oxigênio relativo presente em águas residuárias, efluentes e águas poluídas. O teste possui maior aplicação em plantas de tratamento e na eficiência de remoção do

DBO de estações de tratamento. O teste mede o oxigênio molecular utilizado durante um período de incubação especifico pela degradação bioquímica do material orgânico (demanda de carbonatos) e o oxigênio utilizado para oxidar material 
inorgânico como os sulfitos e íons ferrosos. O teste também pode ser utilizado para quantificar o oxigênio utilizado para oxidar formas reduzidas de nitrogênio (demanda de nitratos) a menos que sua oxidação seja prevenida com a utilização de um inibidor [36].

Para as análises de DBO adiciona-se $95 \mathrm{~mL}$ da amostra a um frasco âmbar, esse frasco possui uma rolha de borracha, com uma cavidade onde adiciona-se hidróxido de lítio. O frasco é fechado com uma tampa que possui uma saída para gás conectada ao leitor de DBO. Após 5 dias de incubação a $20^{\circ} \mathrm{C}$ têm-se os resultados das análises.

\section{4.ÓLEOS E GRAXAS}

Óleos e graxas é definido como qualquer material recuperado solúvel no solvente. Isso inclui outros materiais extraídos pelo solvente de uma amostra acidificada (como compostos sulfurosos, algumas tinturas orgânicas e clorofila) e não volatilizados durante o teste. Na determinação de óleos e graxas, a quantidade de uma substância especifica não é medida. Muitos grupos de substâncias com características físicas similares são determinados quantitativamente com base na sua solubilidade com um solvente orgânico extrator [36].

O processo consiste na adição de $25 \mathrm{~mL}$ da amostra em um balão de fundo chato juntamente com $5 \mathrm{~mL}$ de ácido nítrico concentrado e $5 \mathrm{~mL}$ peróxido de hidrogênio, essa solução é rotoevaporada até restar em torno de $5 \mathrm{~mL}$ de amostra. Retorna-se seu volume novamente para $25 \mathrm{~mL}$, transfere-se a amostra para um funil de separação onde é adicionado $25 \mathrm{~mL}$ de hexano, agita-se vigorosamente e deixa a solução em repouso por $2 \mathrm{~h}$. 
Passado as $2 \mathrm{~h}$, descarta-se a parte aquosa e a parte orgânica é transferida para outro balão de fundo chato previamente tarado, o solvente é rotoevaporado até secar completamente seguindo para estufa a $105^{\circ} \mathrm{C}$ por $1 \mathrm{~h}$. Depois de seco em estufa o balão é esfriado em dessecador e pesado novamente para a determinação dos óleos e graxas.

\subsection{METAIS}

Devido à sua toxicidade, os efeitos dos metais nas águas vão de benéficos até problemáticos. Alguns metais são essenciais para o crescimento de plantas e animais enquanto outros podem afetar seriamente os consumidores da água, sistemas de tratamento de águas e receptores de águas. O efeito benéfico ou tóxico de alguns metais depende de sua concentração.

A espectroscopia de emissão por plasma indutivamente acoplado foi desenvolvida em meados de 1960 como um rápido, sensível e conveniente método para a determinação de metais em amostras de águas e águas residuárias. Os metais dissolvidos são determinados em amostras filtradas e acidificadas, depois de uma digestão apropriada [36].

Na determinação de metais utilizou-se um Espectrofotômetro de Emissão por plasma da marca Perkin Elmer e modelo Optima 3000DV. Para serem analisadas as amostram devem ser digeridas. A digestão é realizada com a adição de $100 \mathrm{~mL}$ da amostra (no caso de amostra sólidas: $5 \mathrm{~g}$ da amostra mais $100 \mathrm{~mL}$ de água destilada) $25 \mathrm{~mL}$ de uma solução $50 \% \mathrm{v} / \mathrm{v}$ de ácido nítrico e deixar sob aquecimento até a redução do seu volume para aproximadamente $50 \mathrm{~mL}$; repetiu-se esse procedimento mais uma vez utilizando $40 \mathrm{~mL}$ da solução de ácido nitrico $50 \%$ v/v. 
Por último adicionou-se $40 \mathrm{~mL}$ de uma solução de $\mathrm{HCl} 50 \%$ v/v mais $40 \mathrm{~mL}$ de água destilada e deixou-se reduzir o volume novamente para $50 \mathrm{~mL}$. Depois de fria, a solução é transferida para um balão volumétrico de $100 \mathrm{~mL}$, completado seu volume com água destilada e então, analisada.

\subsection{SÓLIDOS TOTAIS}

Sólidos é o termo usado para definir a matéria suspensa ou dissolvida na água ou efluente de descarte. Sólidos podem afetar adversamente a qualidade da água ou efluente de várias maneiras. Águas com altas concentrações de sólidos dissolvidos geralmente possuem palatabilidade inferior e podem induzir a reações fisiológicas indesejáveis ao consumidor. Por essas razões, um limite de $500 \mathrm{mg}$ de sólidos dissolvidos/L é aceito para águas potáveis. A análise dos sólidos é importante no controle do processo de tratamento de águas e efluentes.

Sólidos Totais é o termo aplicado ao material resíduário que fica no frasco após evaporação de uma amostra à temperatura definida [36].

A determinação dos sólidos totais consiste na adição de $100 \mathrm{~mL}$ da amostra homogeneizada em um frasco tarado e aquecido em estufa a $100^{\circ} \mathrm{C}$ até a completa evaporação da solução, após o aquecimento, o frasco é esfriado em dessecador e pesado novamente.

\subsection{CROMATOGRAFIA}

Neste trabalho análises cromatográficas foram utilizadas para identificar a presença de compostos orgânicos tóxicos: BTEX, HPAS e Nitrosaminas. 


\section{BTEX}

A presença de BTEX está relacionada ao fato de o fluido de corte apresentar grande quantidade de óleos e graxas.

Contaminação por benzeno, etilbenzeno, tolueno e isômeros de xileno (BTEX), estão associados a produtos derivados do petróleo, como por exemplo, a gasolina que apresenta cerca de 10 a $59 \%$ de compostos aromáticos. Os maiores problemas das contaminações por derivados de petróleo são atribuídos aos hidrocarbonetos monoaromáticos (BTEX), estes compostos são poderosos depressores do sistema nervoso central, e apresentam toxicidade crônica, mesmo em pequenas concentrações (da ordem de ppb), sendo o benzeno o mais tóxico e comprovadamente carcinogênico [37].

Para a extração dos BTEX nas amostras foi utilizada a técnica headspace no modo estático. As extrações dos compostos foram realizadas em triplicata e feitas três leituras cromatográficas. Utilizaram-se vials de $27 \mathrm{~mL}$, aos quais foram adicionadas 10,00 $\mathrm{mL}$ da amostra. Em seguida os vials foram transportados para a encubadora do headspace onde foram aquecidos a uma temperatura constante de $80^{\circ} \mathrm{C}$, por 15 minutos, para promover a volatilização dos analitos. Um volume de $800 \mu \mathrm{L}$ dos analitos foi extraído do vial por uma seringa aquecida, especial para gases, e transportado para o injetor do cromatógrafo e, assim, separado na coluna cromatográfica e quantificado.

A coluna utilizada para a separação dos analitos é a HP1 (30m X 0,25mm). O gás de arraste utilizado é o nitrogênio com um de fluxo de $1,0 \mathrm{~mL} \mathrm{~min}^{-1}$. A rampa de aquecimento utilizada é: $40^{\circ} \mathrm{C}, 5^{\circ} \mathrm{C} \cdot \mathrm{min}^{-1}$ até $60^{\circ} \mathrm{C}$, e $10^{\circ} \mathrm{C} \cdot \mathrm{min}^{-1}$ até $120^{\circ} \mathrm{C}$, totalizando um tempo de análise de 11 minutos. A temperatura utilizada para o injetor é de $220^{\circ} \mathrm{C}$ e para o detector $280^{\circ} \mathrm{C}$. O modo de injeção utilizado é split 1:10. 
O aparelho utilizado para as análises foi um cromatógrafo a gás da marca Shimadzu modelo GC-17A, utilizando um detector de ionização de chama (FID).

$\mathrm{Na}$ Tabela 2 encontram-se os tempos de retenção de uma mistura de BTEX nas condições mencionadas acima.

Tabela 2: Tempo de retenção obtido para uma mistura de BTEX padrão, utilizandose um cromatógrafo a gás com detector de ionização de chama

\begin{tabular}{cc}
\hline Composto & $\begin{array}{c}\text { Tempo de Retenção } \\
\text { (min.) } \\
1,52\end{array}$ \\
Benzeno & 2,36 \\
Tolueno & 3,72 \\
Etilbenzeno & 3,83 \\
Xileno(m,p) & 4,32 \\
Xileno (o) & \\
\hline \hline
\end{tabular}

\section{HPAs}

Os hidrocarbonetos policíclicos aromáticos (HPAs) são compostos que possuem dois ou mais anéis aromáticos condensados em sua estrutura, eles representam uma importante classe de carcinógenos químicos formados durante a combustão incompleta de material orgânico [38].

Os HPAs são poluentes orgânicos de importância ambiental e interesse toxicológico, pois muitos apresentam propriedades pré-carcinogênicas e/ou mutagênicas para homens e animais. Em função deste fato, a legislação vem se tornando cada vez mais restritiva e a fiscalização mais presente [39].

Os HPAs podem ser introduzidos no ambiente a partir de numerosas fontes: os motores de exaustão a gasolina e especialmente os de combustão a diesel, o "alcatrão" da fumaça do cigarro, a superfície dos alimentos chamuscados ou queimados, fumaça da queima de madeira ou carvão, e outros processos de 
combustão parcial, nos quais o carbono ou combustível não são convertidos em CO ou $\mathrm{CO}_{2}[38]$.

Os 16 HPAs considerados como prioritários, da perspectiva dos efeitos adversos à saúde humana, pela Agência de Proteção Ambiental dos Estados Unidos (US EPA, 2001), por serem os mais tóxicos e exibirem maior possibilidade de exposição à população humana são: acenaftileno, acenafteno, antraceno, fluoreno, fluoranteno, naftaleno, pireno, fenantreno e benzo(g,h,i)perileno (não classificados pela USEPA como cancerígenos humanos); e benzo(a)antraceno, benzo(a)pireno, benzo(b)fluoranteno, benzo(k)fluoranteno, dibenzo(a,h)antraceno, Indeno(1,2,3-cd), criseno e pireno (classificados como prováveis cancerígenos humanos) [40].

Para a determinação de HPAs transfere-se uma amostra de $100 \mathrm{~mL}$ para um funil de separação, adicionam-se $10,00 \mathrm{~mL}$ de uma mistura de solventes hexano/acetona 80/20 v/v. A amostra é agitada vigorosamente e deixada em repouso até a completa separação das fases. A fase orgânica é armazenada e uma alíquota de $2 \mu \mathrm{L}$ é injetada no cromatógrafo.

A coluna utilizada para a separação dos analitos é a HP1 (30m X 0,25mm). Nitrogênio é usado como gás de arraste com uma razão de fluxo de $1,0 \mathrm{~mL} \mathrm{~min}{ }^{-1}$. A rampa de aquecimento utilizada é: $35^{\circ} \mathrm{C}$, e $10^{\circ} \mathrm{C} \cdot \mathrm{min}^{-1}$ até $265^{\circ} \mathrm{C}$ onde permanece por 12 minutos, totalizando um tempo de análise de 35 minutos. A temperatura utilizada para o injetor é de $220^{\circ} \mathrm{C}$ e para o detector $280^{\circ} \mathrm{C}$. O modo de injeção utilizado é split 1:10.

O apararelho utilizado para as análises foi um cromatografo gasoso da marca Shimadzu modelo GC-17A, utilizando um detector FID.

$\mathrm{Na}$ Tabela 3 encontram-se os tempos de retenção de uma mistura de HPAs obtido no aparelho e condições mencionadas acima. 
Tabela 3: Tempo de retenção obtido para uma mistura de HPAs padrão, utilizando-se um cromatógrafo a gás com detector de ionização de chama

\begin{tabular}{cc}
\hline \hline Composto & $\begin{array}{c}\text { Tempo de Retenção } \\
\text { (min) }\end{array}$ \\
Naftaleno & 4,15 \\
Acenaftaleno & 6,30 \\
Acenafteno & 6,72 \\
Fluoreno & 7,96 \\
Fenantreno & 10,30 \\
Antraceno & 10,41 \\
Fluoranteno & 13,33 \\
Pireno & 13,78 \\
Criseno & 17,08 \\
Benzo $(\mathrm{k})$ & 19,49 \\
Benzo $(\mathrm{a})$ & 20,22 \\
Indeno & 22,67 \\
Benzo $(\mathrm{g}, \mathrm{h}, \mathrm{i})$ & 23,25 \\
\hline
\end{tabular}

\section{NITROSAMINAS}

O termo nitrosaminas reúne uma grande variedade de tipos estruturais de compostos de diferentes massas moleculares, que surgem como produtos da reação de aminas ou aminoderivados com agentes nitrosantes. A característica estrutural comum é a presença do grupo funcional N-NO, incluindo nitrosaminas e nitrosamidas. Essa classe de compostos, muitos dos quais carcinogênicos, foi estudada em vários materiais, como gêneros alimentícios, produtos farmacêuticos, amostras ambientais (água, solo, ar etc.), pesticidas, herbicidas, borracha, cosméticos etc. Em função do potencial mutagênico e carcinogênico destes compostos em animais, estima-se que o nível de exposição tolerável pelo homem para as nitrosaminas mais voláteis encontra-se na faixa de 5 a $10 \mu \mathrm{g} \cdot \mathrm{kg}^{-1}$, por esta razão o limite de detecção mínimo de $10 \mu \mathrm{g} \cdot \mathrm{kg}^{-1}$ é geralmente aceito [41]. 
Para a determinação de nitrosaminas utilizam-se vials com volume conhecido, aos quais são adicionadas $10 \mathrm{~mL}$ da amostra, em seguida os vials são transportados para a incubadora do Headspace onde são aquecidos a uma temperatura constante de $80^{\circ} \mathrm{C}$ para promover a volatilização dos analitos. Os analitos são extraídos do vial por uma seringa aquecida, especial para headspace, e transportados para o injetor do cromatógrafo e, assim, separados e quantificados na coluna cromatográfica.

A coluna utilizada para a separação dos analitos é a HP5 (30m X 0,25mm). Hêlio é usado como gás de arraste com uma razão de fluxo de $1,0 \mathrm{~mL}$ min-1. A rampa de aquecimento utilizada é: $40^{\circ} \mathrm{C}$, e $10^{\circ} \mathrm{C} \cdot \mathrm{min}^{-1}$ até $250^{\circ} \mathrm{C}$ onde permanece por 4 minutos, totalizando um tempo de análise de 25 minutos. A temperatura utilizada para o injetor é de $250^{\circ} \mathrm{C}$, temperatura da linha de transferência $180^{\circ} \mathrm{C}$ e para o detector de massas temperatura de $260^{\circ} \mathrm{C}$. O modo de injeção utilizado é split $1: 10$

O apararelho utilizado para as análises foi um cromatografo gasoso da marca Shimadzu, modelo GCMS-QP2010 Plus, utilizando um detector de massas. 


\section{CAPÍTULO 5: \\ PROCEDIMENTO

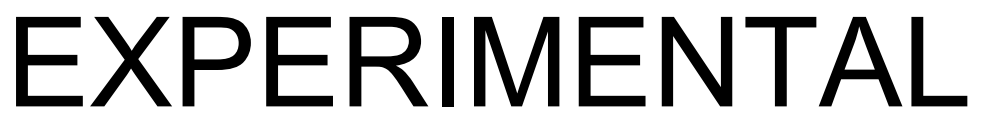

este trabalho comparou-se a eficiência da hidrólise ácida e dos
Processos Oxidativos Fenton e foto-Fenton no tratamento químico de resíduos de fluidos de corte sintéticos. A avaliação do efluente gerado após os testes foi baseada segundo o Decreto $n^{\circ} 8.468$, de 8 de setembro de 1976, que aprova o Regulamento da Lei $n^{\circ}$ 997, de 31 de maio de 1976, que dispõe sobre a Prevenção e o Controle da Poluição do Meio Ambiente [42].

Inicialmente caracterizou-se a amostra de fluido de corte sintético antes ser utilizado nos processos de usinagem, esta caracterização é necessária para obter as características físico-químicas e avaliar as mudanças ocorridas durante o processo.

O próximo passo consistiu na avaliação do fluido na etapa intermediária, ou seja, após ser utilizado e antes de ser tratado, nessa etapa pode-se referir à solução como resíduo de fluido de corte, pois o mesmo encontra-se em fase de descarte. Os resultados dessa análise possibilitam planejar os experimentos a fim de encontrar a relação máxima de custo-benefício do processo de descarte. 
Depois de realizados esses testes inicia-se a fase de tratamento dos resíduos de fluido de corte, que é dividida em duas etapas:

Inicialmente, há a necessidade da separação do óleo mineral da fase aquosa. O óleo de corte, como mencionado na revisão bibliográfica, pode ser reciclado retornando ao mercado ou mesmo ser utilizado como combustível em caldeiras, desde que isentos de produtos nocivos à saúde (clorados, aromáticos etc). O óleo mineral está presente nos resíduos de fluido de corte uma vez que as peças a serem usinadas possuem um revestimento oleoso, necessário para prevenir a sua oxidação.

O fluido de corte aquoso, resíduo de nosso interesse, deve passar por tratamento químico antes de ser descartado, neste processo ocorre a quebra dos polímeros presentes na solução bem como a precipitação dos metais.

Vale ressaltar que todas as determinações experimentais foram realizadas, no mínimo, em triplicata.

\subsection{HIDRÓLISE ÁCIDA}

Consiste na adição de ácido ao fluido de corte até atingir pH entre 2,0 e 3,0, levando à quebra dos polímeros presentes no meio. Após essa quebra, adiciona-se base para promover a formação de precipitado coloidal que auxilia na remoção do polímero hidrolisado bem como dos metais presentes no meio (Figura 3). 


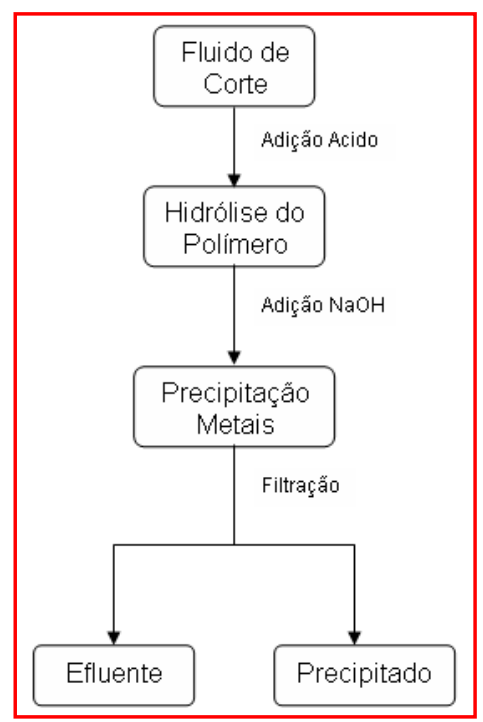

Figura 3: Diagrama do processo de hidrólise ácida utilizado no tratamento de resíduos de fluidos de corte.

Após a remoção da fração sólida, a água é analisada por meio de espectroscopia de absorção atômica por plasma, com a finalidade de detectar metais. Caso seja constatada a presença dos mesmos acima dos limites estabelecidos, a solução passa por processos analíticos de precipitação, sendo analisada novamente. Não havendo a presença de metais, a água pode ser descartada, ou mesmo reaproveitada, retornando ao processo na constituição de um novo fluido de corte.

Comparou-se a viabilidade de diferentes ácidos no processo; observando a eficiência e os custos da utilização dos mesmos. Utilizou-se nos testes ácido tricloroacético, ácido tricloroacético mais carvão ativado e cloreto férrico.

A Tabela 4 apresenta as condições experimentais de cada reação. Utilizou-se ácido tricloroacético, ácido tricloroacético mais carvão ativo e cloreto férrico para a realização do Experimento 01, Experimento 02 e Experimento 03, respectivamente. O ácido tricloroacético utilizado é de grau analítico, o cloreto férrico e o hidróxido de sódio são produtos de grau comercial, sendo o cloreto férrico com concentração de 
$38 \%$ de acordo com a ficha do fabricante e o hidróxido de sódio uma solução saturada contendo $50 \% \mathrm{~m} / \mathrm{m}$.

Tabela 4: Condições experimentais utilizadas para a hidrólise ácida de amostras de fluido de corte

\begin{tabular}{cccccc}
\hline \hline & $\begin{array}{c}\text { pH } \\
\text { inicial }\end{array}$ & $\begin{array}{c}\text { Vol. ácido } \\
(\mathbf{m L})\end{array}$ & $\begin{array}{c}\mathbf{p H} \\
\text { interme- } \\
\text { diário }\end{array}$ & $\begin{array}{c}\text { Vol. NaOH } \\
(\mathbf{m L})\end{array}$ & $\begin{array}{c}\mathbf{p H} \\
\text { final }\end{array}$ \\
Exper. 01 & 8,5 & 15,0 & 3,0 & 4,3 & 7,4 \\
Exper. 02 & 8,5 & 15,0 & 3,1 & 4,5 & 7,3 \\
Exper. 03 & 8,5 & 4,0 & 3,3 & 7,0 & 7,5 \\
\hline \hline
\end{tabular}

\subsection{SISTEMA FENTON}

Em um balão de três bocas equipado com um agitador magnético, termômetro, funil de separação e um condensador com saída para gás é adicionada a amostra para oxidação juntamente com quantidade de sulfato ferroso heptahidratado $\left(\mathrm{FeSO}_{4} .7 \mathrm{H}_{2} \mathrm{O}\right)$ p.a. A mistura é deixada sob agitação até a dissolução completa do sal. $\mathrm{O}$ pH da solução é ajustado para um intervalo compreendido de 3-5 com a adição de ácido sulfúrico p.a. Após o ajuste do pH adiciona-se peróxido de hidrogênio por um período de quatro horas.

A reação é controlada pela adição do peróxido de hidrogênio, nestes experimentos por 1 hora; após o término da adição neutraliza-se a solução ocorrendo a formação de precipitado de hidróxido de ferro. Para a neutralização é utilizada solução de $\mathrm{NaOH}$ de grau comercial $(50 \% \mathrm{~m} / \mathrm{m})$, em seguida a solução é filtrada e os resíduos sólidos e líquidos seguem para análise e classificação (Figura $4)$. 


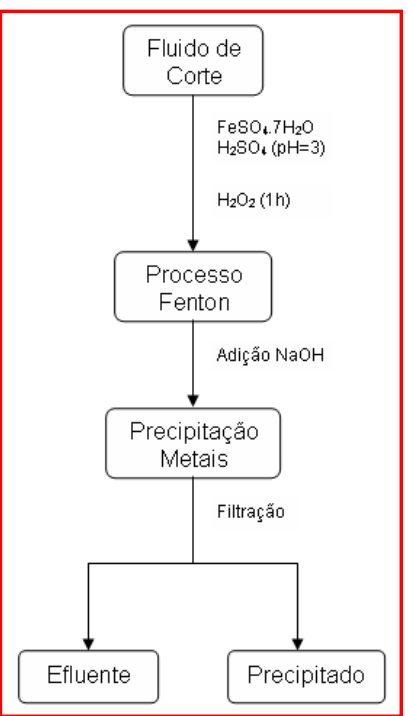

Figura 4: Diagrama do processo de hidrólise ácida utilizado no tratamento de resíduos de fluidos de corte.

Após a remoção da fração sólida, a água é analisada por meio de espectroscopia de absorção atômica por plasma, com a finalidade de detectar metais. Caso seja constatada a presença dos mesmos em valores acima do limite de descarte, a solução passa por processos analíticos de precipitação, sendo analisada novamente. Não havendo a presença de metais, a água pode ser descartada, ou mesmo reaproveitada, retornando ao processo na constituição de um novo fluido de corte. A determinação de metais na fração sólida é necessária para seu correto descarte.

Devido à elevada concentração de carbono orgânico total (COT) iniciaram-se os testes com altas concentrações de Reagente de Fenton, dessa forma pode-se determinar os limites mínimos de reagentes a serem utilizados para um bom desempenho da reação. Na Tabela 5 encontram-se as condições utilizadas para os experimentos com o Reagente de Fenton. 
Tabela 5: Condições experimentais utilizadas para o Processo Fenton em amostras de fluido de corte

\begin{tabular}{cccccccc}
\hline \hline & $\begin{array}{c}\mathrm{pH} \\
\text { inicial }\end{array}$ & $\begin{array}{c}\mathrm{H}_{2} \mathbf{S O}_{4} \text { conc. } \\
(\mathbf{m L})\end{array}$ & $\begin{array}{c}\mathrm{pH} \\
\text { interme- } \\
\text { diário }\end{array}$ & $\begin{array}{c}{\left[\mathrm{Fe}^{+2}\right]} \\
\left(\mathbf{m m o l} \mathbf{L}^{-1}\right)\end{array}$ & $\begin{array}{c}\left.\mathrm{H}_{2} \mathbf{O}_{2}\right] \\
\left(\mathbf{m m o l ~ L}^{-1}\right)\end{array}$ & $\begin{array}{c}\mathrm{NaOH} \\
\mathbf{s a t u r a d a} \\
(\mathbf{m L})\end{array}$ & $\begin{array}{c}\mathbf{p H} \\
\text { final }\end{array}$ \\
Exper. 04 & 9,0 & 2,5 & 3,5 & 22,5 & 1100,00 & 5,0 & 7,2 \\
Exper. 05 & 9,0 & 2,5 & 3,1 & 15,00 & 735,00 & 5,3 & 7,5 \\
Exper. 06 & 9,0 & 2,5 & 3,3 & 15,00 & 600,00 & 5,2 & 7,0 \\
Exper. 07 & 9,0 & 2,5 & 3,0 & 10,00 & 500,00 & 5,2 & 7,3 \\
Exper. 08 & 9,0 & 2,5 & 3,4 & 5,00 & 400,00 & 5,4 & 7,3 \\
Exper. 09 & 9,0 & 2,5 & 3,3 & 1,00 & 200,00 & 5,5 & 7,2 \\
Exper. 10 & 9,0 & 2,5 & 3,0 & 0,05 & 400,00 & 5,4 & 7,0 \\
\hline \hline
\end{tabular}

Realizaram-se os experimentos à temperatura de 25 a $27^{\circ} \mathrm{C}$, todos os reagentes, com exceção do hidróxido de sódio, são de grau analítico. Os experimentos 08, 09 e 10 foram realizados após testes de foto-Fenton, seguindo os mesmos parâmetros, para efeito de comparação dos métodos (adição de peróxido de hidrogênio por período de 5 horas).

\subsection{SISTEMA FOTO-FENTON}

Para a oxidação via sistema foto-Fenton, utiliza-se um reator com um reservatório de 4,5L com um sistema de agitação, uma bomba centrífuga circula a solução do reservatório para um sistema isolado onde se encontra uma coluna de quartzo. Essa coluna possui uma cavidade na parte superior, isolada do líquido que circula por ela, onde é colocada a lâmpada de mercúrio (potência de 250W). A temperatura do reservatório é mantida constante a $23^{\circ} \mathrm{C}$ através da circulação de 
água por um compartimento externo ao reservatório de $4,5 \mathrm{~L}$, formando uma "camisa de água".

A parte experimental consistiu na adição de sulfato ferroso heptahidratado ao reservatório que já se encontrava sob agitação, corrigido o pH para um intervalo de 3 a 5 com ácido sulfúrico concentrado. O processo inicia-se com o acionamento da lâmpada e a adição do peróxido de hidrogênio por 1 hora. Essa é a etapa lenta, pois o peróxido de hidrogênio é adicionado através de uma bomba peristáltica durante 5 horas. No final da reação, a solução é neutralizada e o sobrenadante e precipitado são analisados. O processo é acompanhado por analise de carbono orgânico total (Figura 5).

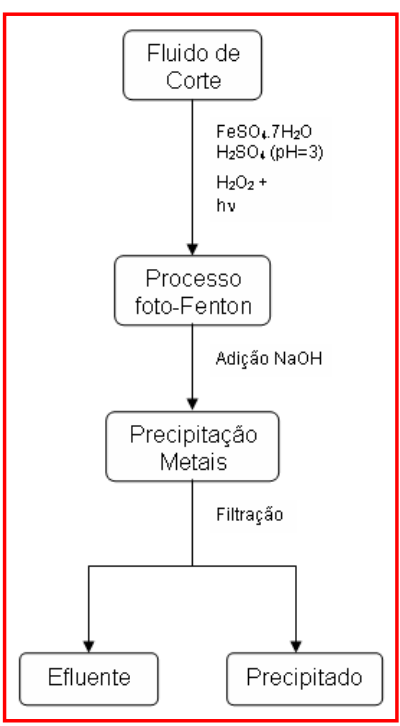

Figura 5: Diagrama do processo de hidrólise ácida utilizado no tratamento de resíduos de fluidos de corte.

$\mathrm{Na}$ Tabela 6 encontram-se as condições utilizadas para cada teste de oxidação, todos os reagentes, com exceção do hidróxido de sódio, são de grau analítico. 
Tabela 6: Condições experimentais utilizadas para o Processo Fenton em amostras de fluido de corte

\begin{tabular}{cccccccc}
\hline \hline & $\begin{array}{c}\mathbf{p H} \\
\text { inicial }\end{array}$ & $\begin{array}{c}\mathrm{H}_{2} \mathbf{S O}_{4} \text { conc. } \\
(\mathbf{m L})\end{array}$ & $\begin{array}{c}\mathrm{pH} \\
\text { interme- } \\
\text { diário }\end{array}$ & $\begin{array}{c}{\left[\mathrm{Fe}^{+2}\right]} \\
\left(\mathbf{m m o l ~ L}^{-1}\right)\end{array}$ & $\begin{array}{c}\left.\mathrm{HH}_{2} \mathrm{O}_{2}\right] \\
\left(\mathbf{m m o l ~ L}^{-1}\right)\end{array}$ & $\begin{array}{c}\mathrm{NaOH} \\
\mathbf{s a t u r a d} \\
\mathbf{0}(\mathbf{m L})\end{array}$ & $\begin{array}{c}\mathbf{p H} \\
\text { final }\end{array}$ \\
Exper. 11 & 9,0 & 2,5 & 3,2 & 0,05 & 200,00 & 4,5 & 7,3 \\
Exper. 12 & 9,0 & 2,5 & 3,4 & 5,00 & 400,00 & 5,1 & 7,0 \\
Exper. 13 & 9,0 & 2,5 & 3,5 & 1,00 & 400,00 & 4,8 & 7,5 \\
\hline \hline
\end{tabular}




\section{CAPÍTULO 6: \\ RESULTADOS E \\ DISCUSSÃO}

\subsection{CARACTERIZAÇÃO DO FLUIDO DE CORTE PRÉ E PÓS PROCESSO DE USINAGEM.}

O processo de usinagem por ser fisicamente agressivo (alta temperatura na região de corte), apresenta mudanças na estrutura química e consequentemente na composição do fluido de corte, essas mudanças podem ser observadas na Tabela 7. A análise dos dados nos permite concluir que todos os parâmetros diminuem de concentração, devido às altas temperaturas que a solução é submetida ao entrar em contato com a região de corte $\left(200\right.$ a $\left.300^{\circ} \mathrm{C}\right)$. Na degradação ocorre desprendimento de $\mathrm{CO}_{2}$ e $\mathrm{NO}_{2}$, o que faz com que ocorra uma diminuição no COT. 
Tabela 7: Caracterização química do fluido de corte antes e após utilização no processo de usinagem

\begin{tabular}{|c|c|c|}
\hline & $\begin{array}{l}\text { Antes do } \\
\text { Processo de } \\
\text { Usinagem } \\
\left(\mathrm{mg} \mathrm{L}^{-1}\right)\end{array}$ & $\begin{array}{c}\text { Após o } \\
\text { Processo de } \\
\text { usinagem } \\
\left(\mathrm{mg} \mathrm{L}^{-1}\right)\end{array}$ \\
\hline DBO & $20000,00 \pm 0,01$ & $5000,00 \pm 0,01$ \\
\hline DQO & $82128,00 \pm 0,05$ & $17000,00 \pm 0,05$ \\
\hline $\begin{array}{l}\text { Óleos e } \\
\text { Graxas }\end{array}$ & $16532,0 \pm 0,5$ & $9942,0 \pm 0,5$ \\
\hline СOT & $185300,0 \pm 0,1$ & $11435,0 \pm 0,1$ \\
\hline $\begin{array}{l}\text { Sólidos } \\
\text { Totais }\end{array}$ & $82460,0 \pm 0,5$ & $11700 \pm 0,5$ \\
\hline \multicolumn{3}{|l|}{ Metais } \\
\hline $\mathrm{Zn}$ & nd & $5,680 \pm 0,001$ \\
\hline $\mathrm{Pb}$ & nd & $0,105 \pm 0,001$ \\
\hline Cd & nd & $0,000 \pm 0,001$ \\
\hline $\mathrm{Ni}$ & nd & $0,219 \pm 0,001$ \\
\hline $\mathbf{F e}$ & $0,680 \pm 0,001$ & $31,400 \pm 0,001$ \\
\hline$M n$ & nd & $0,085 \pm 0,001$ \\
\hline $\mathrm{Cu}$ & nd & $1,750 \pm 0,001$ \\
\hline $\mathrm{Cr}$ & nd & $0,242 \pm 0,001$ \\
\hline Al & nd & $4,81 \pm 0,001$ \\
\hline
\end{tabular}

A diminuição nos óleos e graxas está relacionada à diminuição na concentração do polímero. A análise de óleos e graxas não é seletiva, ou seja, o resultado depende da solubilidade dos componentes no solvente orgânico, por o fluido possuir características de lubrificação, ou seja, características parecidas com o óleo lubrificante, quanto menor a concentração de polímero menor a concentração de óleos e graxas.

Como era de se esperar, a concentração de metais aumentou no fluido após a utilização do mesmo nos processos de usinagem. Esse fato deve-se aos processos redutivos que ocorrem com a peça ao ser usinada. 


\subsection{HIDRÓLISE ÁCIDA}

No processo de hidrólise, ao atingir $\mathrm{pH} 3$, ocorre a quebra das ligações do polímero, cuja quebra resulta na floculação da amostra. Ao neutralizar a solução ocorre a formação de precipitado dos metais presentes na solução. Na Figura 5 é observada a floculação da amostra.

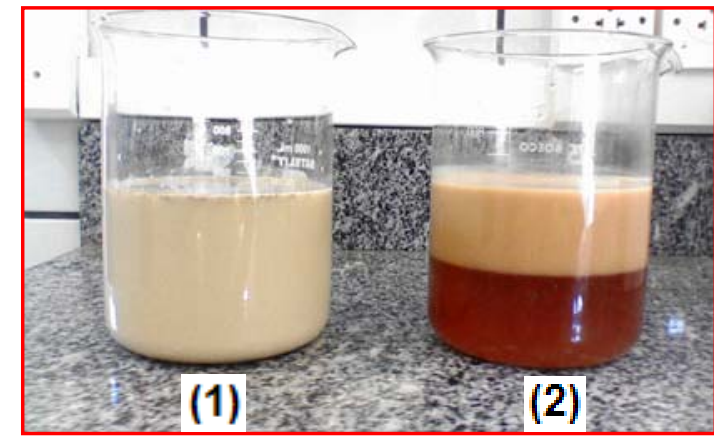

Figura 6: Amostra antes (1) e após (2) a hidrólise ácida

A hidrólise utilizando carvão ativado e cloreto férrico também fornece os mesmos resultados quanto à quebra da amostra, porém diverge nos resultados da análise da fração liquida e sólida. A Tabela 8 apresenta a caracterização do efluente filtrado, após sua hidrólise ácida. 
Tabela 8: Caracterização química do fluido de corte após hidrólise ácida

\begin{tabular}{ccccc}
\hline \hline & $\begin{array}{c}\text { Após o } \\
\text { Processo de } \\
\text { usinagem } \\
\left(\mathrm{mg} \mathrm{L}^{-1}\right)\end{array}$ & $\begin{array}{c}\text { Exper. } \\
\mathbf{0 1} \\
\left(\mathrm{mg} \mathrm{L}^{-1}\right)\end{array}$ & $\begin{array}{c}\text { Exper. } \\
\mathbf{0 2} \\
\left(\mathrm{mg} \mathrm{L}^{-1}\right)\end{array}$ & $\begin{array}{c}\text { Exper. } \\
\mathbf{0 3} \\
\left(\mathrm{mg} \mathrm{L}^{-1}\right)\end{array}$ \\
DBO & $5000,00 \pm 0,01$ & $147,00 \pm 0,01$ & $128,00 \pm 0,01$ & $136,00 \pm 0,01$ \\
DQO & $17000,00 \pm 0,05$ & $6836,00 \pm 0,05$ & $5543,00 \pm 0,05$ & $5790,00 \pm 0,05$ \\
Óleos e & $9942,0 \pm 0,5$ & $890,0 \pm 0,5$ & $713,0 \pm 0,5$ & $821,0 \pm 0,5$ \\
Graxas & $11435,0 \pm 0,1$ & $5275,8 \pm 0,1$ & $4125,8 \pm 0,1$ & $5031,0 \pm 0,1$ \\
COT & $11700,0 \pm 0,5$ & $6210,0 \pm 0,5$ & $6400,0 \pm 0,5$ & $10830,0 \pm 0,5$ \\
Sólidos & & & & \\
Totais & & $0,090 \pm 0,001$ & $0,110 \pm 0,001$ & $0,100 \pm 0,001$ \\
Metais & $5,680 \pm 0,001$ & $0,020 \pm 0,001$ & $0,210 \pm 0,001$ & $0,070 \pm 0,001$ \\
Zn & $0,110 \pm 0,001$ & $0,040 \pm 0,001$ & $0,230 \pm 0,001$ & $0,170 \pm 0,001$ \\
Pb & $0,220 \pm 0,001$ & $3,080 \pm 0,001$ & $3,030 \pm 0,001$ & $25,000 \pm 0,001$ \\
Ni & $31,400 \pm 0,001$ & $12,000 \pm 0,001$ & $18,320 \pm 0,001$ & $19,250 \pm 0,001$ \\
Fe & $20,080 \pm 0,001$ & $0,070 \pm 0,001$ & $0,080 \pm 0,001$ & $0,050 \pm 0,001$ \\
Mn & $1,750 \pm 0,001$ & $0,100 \pm 0,001$ & $0,260 \pm 0,001$ & $0,190 \pm 0,001$ \\
\hline Cu & $0,240 \pm 0,001$ & & & \\
Cr & & & & \\
\hline
\end{tabular}

A utilização do ácido tricloroacético mais carvão ativo (experimento 02) para a hidrolise ácida do fluido de corte não é interessante, devido à formação de uma quantidade maior de precipitado, sem redução significativa nos parâmetros estudados. O mesmo ocorre com a utilização do cloreto férrico (experimento 03), quando comparados aos parâmetros orgânicos (DBO, DQO, COT e Óleos e Graxas). O experimento 03 apresenta valores mais interessantes do que o experimento 01 (ácido tricloroacético), porém devido à grande quantidade de ferro adicionado à solução, não há uma variação significativa nos sólidos totais e a quantidade de ferro restante no meio após a precipitação ainda está acima do permitido pela legislação [42].

A Figura 7 apresenta os precipitados, após secos, formados no tratamento de $500 \mathrm{~mL}$ de fluido de corte utilizando os três processos descritos. O precipitado 1 
corresponde ao formado pelo ácido tricloroacético (Experimento 01), o precipitado 2 apresenta uma coloração mais escura devido à presença do carvão foi tratado com ácido tricloroacético mais carvão ativo (Experimento 02) e o precipitado 3 - mais avermelhado - corresponde ao tratado com cloreto férrico (Experimento 03).

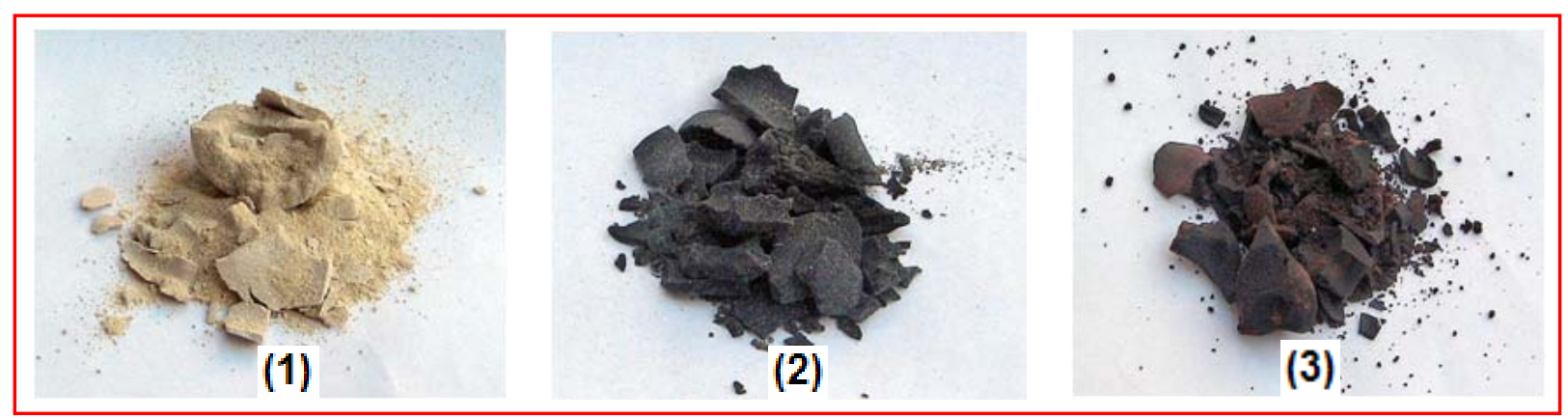

Figura 7: Precipitados formados na neutralização do processo da hidrolise ácida: (1) ácido tricloroacético, (2) ácido tricloroacético mais carvão ativo e (3) cloreto férrico.

A Tabela 9 apresenta os principais metais encontrados na análise dos precipitados, que se enquadram como resíduos de classe I (perigoso, tóxico), segundo a NBR 10004 [43].

Tabela 9: Caracterização dos metais presentes no precipitado dos testes utilizando hidrólise

\begin{tabular}{cccc}
\multicolumn{3}{c}{ ácida } \\
\hline \hline & $\begin{array}{c}\text { Exper. } \\
\mathbf{0 1} \\
\left(\mathrm{mg} \mathrm{kg}^{-1}\right)\end{array}$ & $\begin{array}{c}\text { Exper. } \\
\mathbf{0 2} \\
\left(\mathrm{mg} \mathrm{kg}^{-1}\right)\end{array}$ & $\begin{array}{c}\text { Exper. } \\
\mathbf{0 3} \\
\left(\mathrm{mg} \mathrm{kg}^{-1}\right)\end{array}$ \\
Zn & $0,730 \pm 0,001$ & $0,640 \pm 0,001$ & $0,600 \pm 0,001$ \\
Fe & $2,410 \pm 0,001$ & $1,420 \pm 0,001$ & $163,790 \pm 0,001$ \\
Mn & $4,530 \pm 0,001$ & $2,690 \pm 0,001$ & $3,550 \pm 0,001$ \\
\hline \hline
\end{tabular}




\subsection{PROCESSO FENTON}

No Processo Fenton a oxidação da matéria orgânica pelos radicais hidroxila pode ser observada pela formação de precipitados na solução após o inicio da adição de peróxido de hidrogênio (Figura 8).

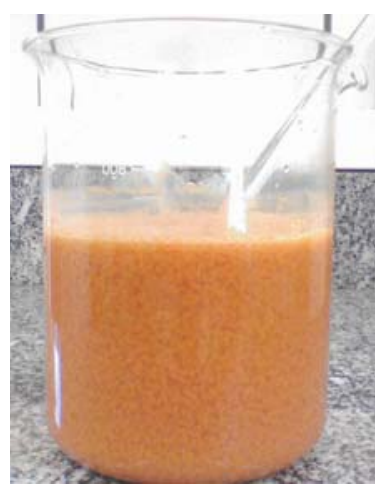

Figura 8: Formação de precipitado no Processo Fenton.

Devido à grande quantidade de compostos existentes no fluido e por ser um produto comercial não se tem acesso à composição. Além disso, no processo Fenton ocorre a geração de compostos intermediários como ácidos carboxílicos que interferem em certos tipos de análises. Dessa forma, a eficiência do processo é medida de acordo com a quantidade total de matéria orgânica presente na solução, ou seja, o carbono orgânico total.

A Tabela 10 apresenta os resultados dos experimentos 04 ao 07 , nos quais se variaram as concentrações de reagentes utilizados no processo (Tabela 5, pag.47). 
Tabela 10: Caracterização química do fluido de corte após Processo Fenton

\begin{tabular}{|c|c|c|c|c|c|}
\hline & $\begin{array}{c}\text { Após o } \\
\text { Processo de } \\
\text { usinagem } \\
\left(\mathrm{mg} \mathrm{L}^{-1}\right)\end{array}$ & $\begin{array}{c}\text { Exper. } \\
04 \\
\left(\mathrm{mg} \mathrm{L}^{-1}\right)\end{array}$ & $\begin{array}{c}\text { Exper. } \\
05 \\
\left(\mathrm{mg} \mathrm{L}^{-1}\right)\end{array}$ & $\begin{array}{c}\text { Exper. } \\
06 \\
\left(\mathrm{mg} \mathrm{L}^{-1}\right)\end{array}$ & $\begin{array}{c}\text { Exper. } \\
07 \\
\left(\mathrm{mg} \mathrm{L}^{-1}\right)\end{array}$ \\
\hline DBO & $5000,00 \pm 0,01$ & $108,31 \pm 0,01$ & $87,40 \pm 0,01$ & $101,42 \pm 0,01$ & $96,34 \pm 0,01$ \\
\hline DQO & $17000,00 \pm 0,05$ & $4160,00 \pm 0,05$ & $3660,00 \pm 0,05$ & $3993,60 \pm 0,05$ & $3790,67 \pm 0,05$ \\
\hline $\begin{array}{l}\text { Óleos e } \\
\text { Graxas }\end{array}$ & $9942,0 \pm 0,5$ & $210,4 \pm 0,5$ & $206,2 \pm 0,5$ & $208,7 \pm 0,5$ & $207,4 \pm 0,5$ \\
\hline сот & $11435,0 \pm 0,1$ & $2790,8 \pm 0,1$ & $3123,3 \pm 0,1$ & $3025,3 \pm 0,1$ & $3700,2 \pm 0,1$ \\
\hline $\begin{array}{c}\text { Sólidos } \\
\text { Totais }\end{array}$ & $11700,0 \pm 0,5$ & $5810,0 \pm 0,5$ & $5740,0 \pm 0,5$ & $5600,0 \pm 0,5$ & $5280,0 \pm 0,5$ \\
\hline \multicolumn{6}{|l|}{ Metais } \\
\hline $\mathrm{Zn}$ & $5,680 \pm 0,001$ & $0,430 \pm 0,001$ & $0,760 \pm 0,001$ & $0,900 \pm 0,001$ & $0,980 \pm 0,001$ \\
\hline $\mathrm{Pb}$ & $0,110 \pm 0,001$ & $0,090 \pm 0,001$ & $0,070 \pm 0,001$ & $0,120 \pm 0,001$ & $0,030 \pm 0,001$ \\
\hline $\mathrm{Ni}$ & $0,220 \pm 0,001$ & $0,180 \pm 0,001$ & $0,210 \pm 0,001$ & $0,070 \pm 0,001$ & $0,120 \pm 0,001$ \\
\hline $\mathrm{Fe}$ & $31,400 \pm 0,001$ & $4,220 \pm 0,001$ & $3,520 \pm 0,001$ & $3,470 \pm 0,001$ & $3,020 \pm 0,001$ \\
\hline Mn & $20,080 \pm 0,001$ & $0,090 \pm 0,001$ & $1,250 \pm 0,001$ & $1,480 \pm 0,001$ & $1,120 \pm 0,001$ \\
\hline $\mathrm{Cu}$ & $1,750 \pm 0,001$ & $0,210 \pm 0,001$ & $0,380 \pm 0,001$ & $0,270 \pm 0,001$ & $0,290 \pm 0,001$ \\
\hline $\mathrm{Cr}$ & $0,240 \pm 0,001$ & $0,090 \pm 0,001$ & $0,170 \pm 0,001$ & $0,140 \pm 0,001$ & $0,120 \pm 0,001$ \\
\hline
\end{tabular}

A redução no COT para o experimento 04, 05, 06 e 07 foi de 75,6\%, 72,69\%, $72,68 \%$ e $67,64 \%$, respectivamente. Os testes mostraram que o processo de oxidação pode ser utilizado com concentrações mais baixas de ferro e peróxido, observa-se que devido à reação entre radicais peridróxido e radicais hidroxila um excesso da concentração de peróxido de hidrogênio diminui eficiência do processo. Todos os testes foram conduzidos por um tempo de 4 horas.

A Figura 9 apresenta os resultados da redução no COT em função do tempo de reação para o experimento 04 . Devido às altas concentrações de reagentes a reação é rápida resultando na degradação de uma grande quantidade de matéria orgânica nos primeiros minutos de reação. Após a primeira meia hora de reação a redução no COT é mais lenta. 


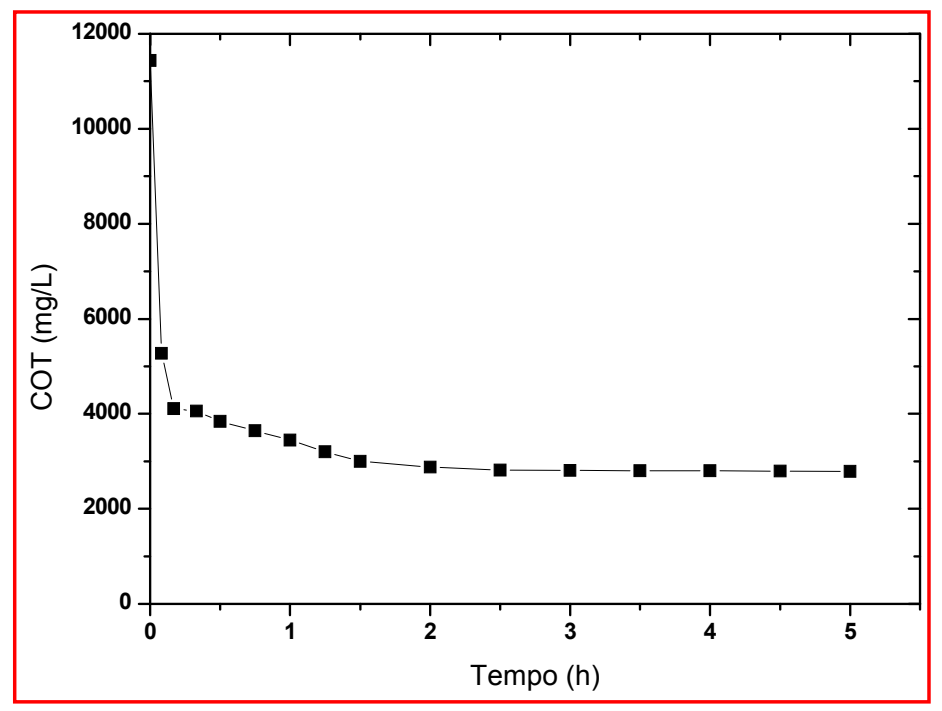

Figura 9: Redução no COT do experimento 04 em função do tempo.

Os experimentos 08, 09 e 10 foram conduzidos sob as mesmas condições realizadas no Processo foto-Fenton (Tabela 5, pag. 47). Nesse processo utiliza-se uma menor quantidade de reagente e um tempo de reação de 5 horas. A Tabela 11 apresenta os resultados obtidos em cada experimento realizado.

Todos os experimentos apresentados mostraram-se satisfatórios para a oxidação de fluido de corte, pois reduziram todos os parâmetros a níveis aceitáveis de descarte. O DBO apresentou uma redução de 98,84\%, 98,66 e 98,76\% para os experimentos 08, 09 e 10, respectivamente. 
Tabela 11: Caracterização química do fluido de corte após Processo Fenton

\begin{tabular}{|c|c|c|c|c|}
\hline & $\begin{array}{c}\text { Após o } \\
\text { Processo de } \\
\text { usinagem } \\
\left(\mathrm{mg} \mathrm{L}^{-1}\right)\end{array}$ & $\begin{array}{c}\text { Exper. } \\
08 \\
\left(\mathrm{mg} \mathrm{L}^{-1}\right)\end{array}$ & $\begin{array}{c}\text { Exper. } \\
09 \\
\left(\mathrm{mg} \mathrm{L}^{-1}\right)\end{array}$ & $\begin{array}{c}\text { Exper. } \\
10 \\
\left(\mathrm{mg} \mathrm{L}^{-1}\right)\end{array}$ \\
\hline DBO & $5000,00 \pm 0,01$ & $58,00 \pm 0,01$ & $67,00 \pm 0,01$ & $62,00 \pm 0,01$ \\
\hline DQO & $17000,00 \pm 0,05$ & $2501,25 \pm 0,05$ & $2601,34 \pm 0,05$ & $2590,33 \pm 0,05$ \\
\hline $\begin{array}{l}\text { Óleos e } \\
\text { Graxas }\end{array}$ & $994,0 \pm 0,5$ & $147,2 \pm 0,5$ & $152,2 \pm 0,5$ & $165,7 \pm 0,5$ \\
\hline COT & $11435,0 \pm 0,1$ & $3127,7 \pm 0,1$ & $4097,4 \pm 0,1$ & $4968,2 \pm 0,1$ \\
\hline $\begin{array}{l}\text { Sólidos } \\
\text { Totais }\end{array}$ & $11700,0 \pm 0,5$ & $5020,0 \pm 0,5$ & $4610,0 \pm 0,5$ & $4090,0 \pm 0,5$ \\
\hline \multicolumn{5}{|l|}{ Metais } \\
\hline $\mathrm{Zn}$ & $5,680 \pm 0,001$ & $1,030 \pm 0,001$ & $1,780 \pm 0,001$ & $1,870 \pm 0,001$ \\
\hline $\mathrm{Pb}$ & $0,110 \pm 0,001$ & nd & nd & nd \\
\hline $\mathrm{Ni}$ & $0,220 \pm 0,001$ & nd & nd & nd \\
\hline $\mathrm{Fe}$ & $31,400 \pm 0,001$ & $2,310 \pm 0,001$ & $1,770 \pm 0,001$ & $2,190 \pm 0,001$ \\
\hline Mn & $20,080 \pm 0,001$ & $0,900 \pm 0,001$ & $0,970 \pm 0,001$ & $0,780 \pm 0,001$ \\
\hline $\mathrm{Cu}$ & $1,750 \pm 0,001$ & $0,360 \pm 0,001$ & $0,040 \pm 0,001$ & $0,440 \pm 0,001$ \\
\hline $\mathrm{Cr}$ & $0,240 \pm 0,001$ & $0,060 \pm 0,001$ & $0,120 \pm 0,001$ & $0,170 \pm 0,001$ \\
\hline
\end{tabular}

nd= não detectado

Obteve-se uma redução no COT de $72,65 \%, 64,17 \%$ e $56,55 \%$, nos experimentos 08, 09 e 10, respectivamente. A Figura 10 apresenta a redução no COT em função do tempo de reação para esses experimentos. 


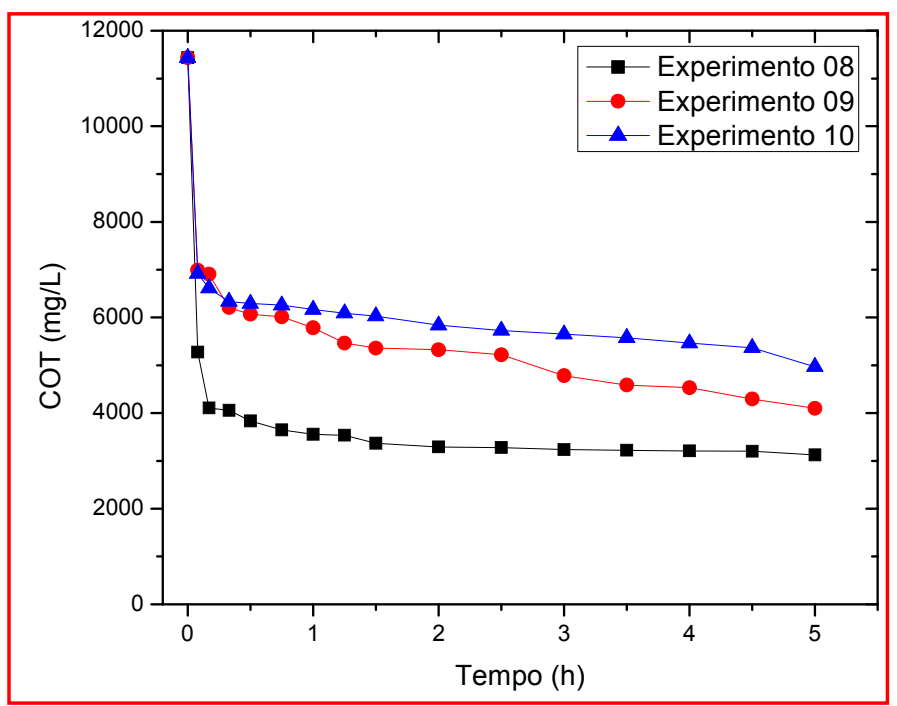

Figura 10: Redução no COT dos experimentos 08, 09 e 10 em função do tempo.

A eficiência do processo no experimento 08 mostrou-se superior em comparação com os experimentos 04 a 07, utilizando, ainda, menor quantidade de reagente (Tabela 5, pag. 47).

Na Tabela 12, encontra-se a concentração de metais presentes no precipitado de cada experimento, de acordo com a concentração dos metais mais significativos esses resíduos se enquadram na classe I [43].

Tabela 12: Caracterização dos metais presentes no precipitado dos testes utilizando Processo Fenton

\begin{tabular}{|c|c|c|c|c|c|c|c|}
\hline & $\begin{array}{c}\text { Exper. } \\
04 \\
\left(\mathrm{mg} \mathrm{kg}^{-1}\right)\end{array}$ & $\begin{array}{c}\text { Exper. } \\
05 \\
\left(\mathrm{mg} \mathrm{kg}^{-1}\right)\end{array}$ & $\begin{array}{c}\text { Exper. } \\
06 \\
\left(\mathrm{mg} \mathrm{kg}^{-1}\right)\end{array}$ & $\begin{array}{c}\text { Exper. } \\
07 \\
\left(\mathrm{mg} \mathrm{kg}^{-1}\right)\end{array}$ & $\begin{array}{c}\text { Exper. } \\
08 \\
\left(\mathrm{mg} \mathrm{kg}^{-1}\right)\end{array}$ & $\begin{array}{c}\text { Exper. } \\
09 \\
\left(\mathrm{mg} \mathrm{kg}^{-1}\right)\end{array}$ & $\begin{array}{c}\text { Exper. } \\
10 \\
\left(\mathrm{mg} \mathrm{kg}^{-1}\right)\end{array}$ \\
\hline $\mathrm{Zn}$ & 0,65 & 0,64 & 0,72 & 0,69 & 0,71 & 0,65 & 0,75 \\
\hline $\mathrm{Fe}$ & 10,31 & 9,87 & 9,92 & 7,03 & 5,61 & 2,04 & 1,21 \\
\hline Mn & 4,47 & 4,31 & 4,27 & 4,35 & 4,21 & 4,33 & 4,23 \\
\hline
\end{tabular}

"Todos os resultados apresentam erro de $\pm 0,01$ 


\subsection{PROCESSO FOTO-FENTON}

Assim como o sistema Fenton, o Processo foto-Fenton oxida os compostos orgânicos, contudo neste último regeneram-se os íons ferrosos que reagem novamente com o peróxido de hidrogênio formando mais radicais hidroxila.

Na Figura 11, encontra-se o equipamento utilizado nos testes de oxidação no CEPEMA, em Cubatão, SP.
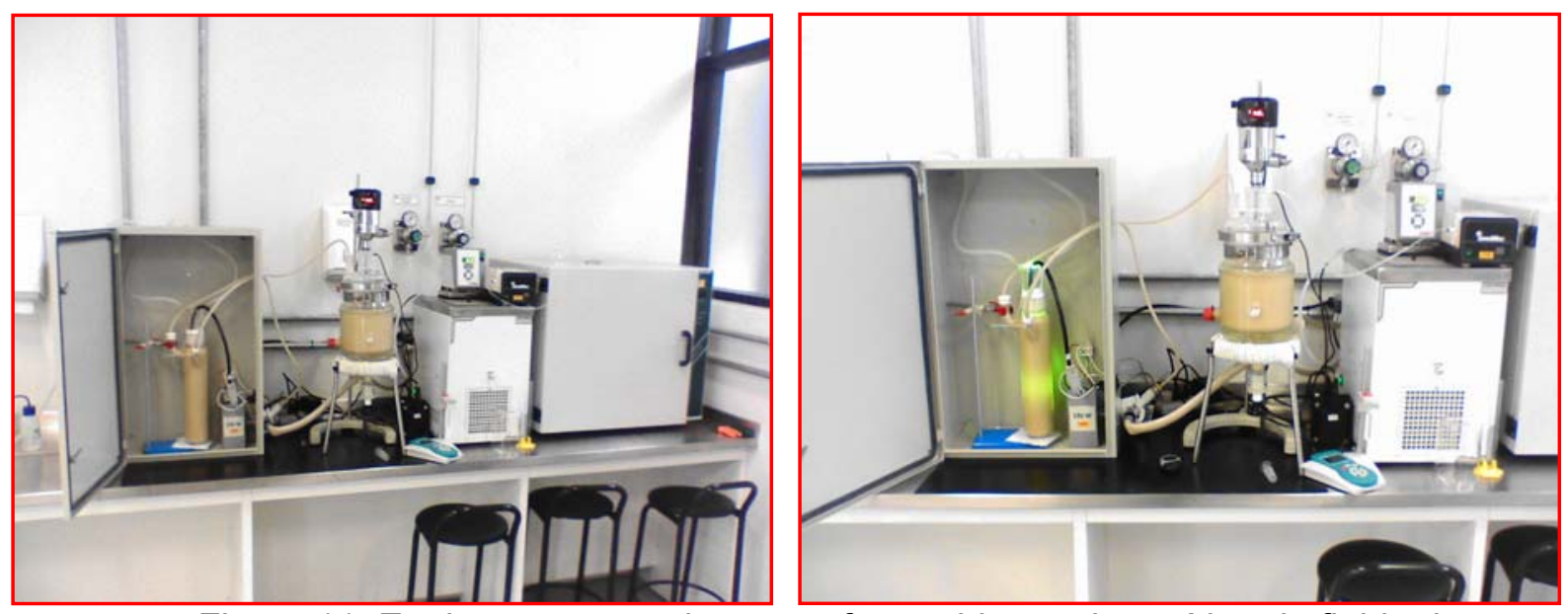

Figura 11: Equipamento usado para a foto-oxidação do resíduo de fluido de corte.

Na Tabela 13 encontram-se os resultados obtidos na oxidação dos resíduos de fluido de corte. Todos os parâmetros analisados encontram-se abaixo do limite de descarte permitido pela legislação [42]. As condições experimentais seguidas nos experimentos estão reportadas na Tabela 6, página 49. 
Tabela 13: Caracterização química do fluido de corte após Processo foto-Fenton

\begin{tabular}{|c|c|c|c|c|}
\hline & $\begin{array}{l}\text { Após o } \\
\text { Processo de } \\
\text { usinagem } \\
\left(\mathrm{mg} \mathrm{L}^{-1}\right)\end{array}$ & $\begin{array}{c}\text { Exper. } \\
11 \\
\left(\mathrm{mg} \mathrm{L}^{-1}\right)\end{array}$ & $\begin{array}{c}\text { Exper. } \\
12 \\
\left(\mathrm{mg} \mathrm{L}^{-1}\right)\end{array}$ & $\begin{array}{c}\text { Exper. } \\
13 \\
\left(\mathrm{mg} \mathrm{L}^{-1}\right)\end{array}$ \\
\hline DBO & $5000,00 \pm 0,01$ & $20,00 \pm 0,01$ & $26,00 \pm 0,01$ & $28,00 \pm 0,01$ \\
\hline DQO & $17000,00 \pm 0,05$ & $2054,32 \pm 0,05$ & $2256,70 \pm 0,05$ & $2397,59 \pm 0,05$ \\
\hline $\begin{array}{l}\text { Óleos e } \\
\text { Graxas }\end{array}$ & $9942,0 \pm 0,5$ & $83,2 \pm 0,5$ & $89,4 \pm 0,5$ & $92,2 \pm 0,5$ \\
\hline COT & $11435,0 \pm 0,1$ & $3260,4 \pm 0,1$ & $3058,1 \pm 0,1$ & $2215,9 \pm 0,1$ \\
\hline $\begin{array}{c}\text { Sólidos } \\
\text { Totais }\end{array}$ & $11700,0 \pm 0,5$ & $3060,0 \pm 0,5$ & $3250,0 \pm 0,5$ & $4030,0 \pm 0,5$ \\
\hline \multicolumn{5}{|l|}{ Metais } \\
\hline $\mathrm{Zn}$ & $5,680 \pm 0,001$ & $2,940 \pm 0,001$ & $2,210 \pm 0,001$ & $2,430 \pm 0,001$ \\
\hline $\mathbf{P b}$ & $0,110 \pm 0,001$ & nd & nd & $0,080 \pm 0,001$ \\
\hline $\mathbf{N i}$ & $0,220 \pm 0,001$ & nd & nd & nd \\
\hline $\mathrm{Fe}$ & $31,400 \pm 0,001$ & $12,900 \pm 0,001$ & $22,180 \pm 0,001$ & $19,950 \pm 0,001$ \\
\hline Mn & $20,080 \pm 0,001$ & nd & nd & nd \\
\hline $\mathrm{Cu}$ & $1,750 \pm 0,001$ & $1,700 \pm 0,001$ & $11,780 \pm 0,001$ & $8,570 \pm 0,001$ \\
\hline $\mathrm{Cr}$ & $0,240 \pm 0,001$ & $0,320 \pm 0,001$ & $0,580 \pm 0,001$ & $0,510 \pm 0,001$ \\
\hline
\end{tabular}

A DBO apresentou redução de $99,60 \%, 99,48 \%$ e $99,44 \%$ e o COT de $71,49 \%, 73,26 \%$ e $80,62 \%$, respectivamente, para os experimentos 11,12 e $13 . \mathrm{Na}$ Figura 12, encontram-se as curvas de COT em função do tempo de reação. 


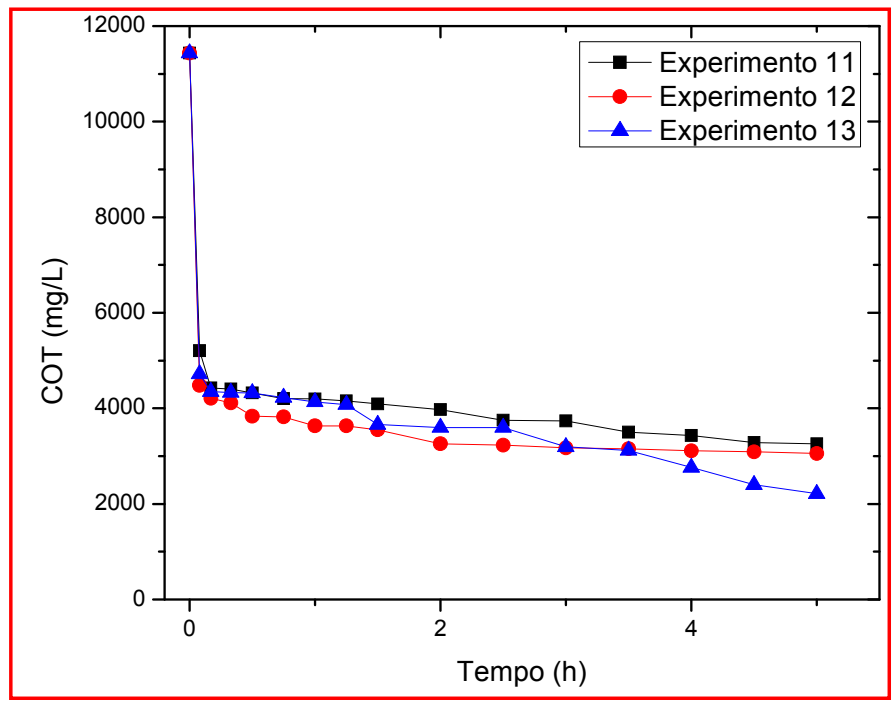

Figura 12: Redução no COT dos experimentos 11, 12 e 13 em função do tempo.

Todos os testes apresentaram bons resultados na oxidação, porém foi o experimento 13 que apresentou melhor eficiência.

As concentrações dos metais, presentes no precipitado formado na neutralização da solução, encontram-se na Tabela 14. Esse resíduo é classificado como sendo de classe I [43].

Tabela 14: Caracterização dos metais presentes no precipitado dos testes utilizando hidrólise ácida

\begin{tabular}{cccc}
\hline \hline & $\begin{array}{c}\text { Exper. } \\
\mathbf{1 1} \\
\left(\mathrm{mg} \mathrm{kg}^{-1}\right)\end{array}$ & $\begin{array}{c}\text { Exper. } \\
\mathbf{1 2} \\
\left(\mathrm{mg} \mathrm{kg}^{-1}\right)\end{array}$ & $\begin{array}{c}\text { Exper. } \\
\mathbf{1 3} \\
\left(\mathrm{mg} \mathrm{kg}^{-1}\right)\end{array}$ \\
Zn & $0,670 \pm 0,001$ & $0,710 \pm 0,001$ & $0,790 \pm 0,001$ \\
Fe & $1,950 \pm 0,001$ & $3,430 \pm 0,001$ & $2,570 \pm 0,001$ \\
Mn & $4,120 \pm 0,001$ & $4,540 \pm 0,001$ & $3,980 \pm 0,001$ \\
\hline
\end{tabular}




\section{CAPÍTULO 7: \\ COMPARAÇÃO DOS \\ MÉTODOS ESTUDADOS}

odos os métodos apresentaram bons resultados no tratamento dos
resíduos de fluido de corte. $\mathrm{Na}$ hidrólise ácida tem-se a facilidade na rapidez do procedimento, porém os parâmetros orgânicos encontram-se um pouco elevados para permitir o descarte; ao comparar as três metodologias utilizadas para a hidrólise ácida o experimento 01 (ácido tricloroacético) foi aquele que apresentou melhores resultados, pois apresentou uma menor quantidade de metais em solução após a neutralização e o resíduo sólido formado não apresenta carvão ativo ou maiores concentrações de ferro, o que se verifica nos outros tratamentos.

O processo Fenton apresentou-se melhor no tratamento de fluidos de corte, pois com baixas concentrações de reagentes conseguiu-se uma redução no COT de $72,65 \%$ (experimento 08), o que é muito bom considerando a concentração de COT inicial e, além disso, uma das características do reagente de Fenton está no fato de que a reação não termina após 4 horas, portanto, teoricamente, esses valores de COT podem reduzir-se ainda mais. No entanto, foi sempre observado que a diminuição de COT é muito pequena após cerca de $1 \mathrm{~h}$ de experimento. 
O processo foto-Fenton apresentou melhores resultados na oxidação das amostras, resultando em uma redução de $80,62 \%$ no COT (experimento 13), porém pelo fato de ser necessária a utilização de uma lâmpada de UV-Vis, o processo torna-se mais oneroso, tanto na montagem quanto na operação do sistema.

Na tabela 15 comparam-se os melhores resultados de cada método, bem como os limites para o descarte.

Tabela 15: Comparação dos resultados obtidos nos diferentes processos de tratamento

\begin{tabular}{|c|c|c|c|c|c|}
\hline & $\begin{array}{l}\text { Após o } \\
\text { Processo de } \\
\text { usinagem } \\
\left(\mathrm{mg} \mathrm{L}^{-1}\right)\end{array}$ & $\begin{array}{c}\text { Exper. } \\
01 \\
\left(\mathrm{mg} \mathrm{kg}^{-1}\right)\end{array}$ & $\begin{array}{c}\text { Exper. } \\
08 \\
\left(\mathrm{mg} \mathrm{kg}^{-1}\right)\end{array}$ & $\begin{array}{c}\text { Exper. } \\
13 \\
\left(\mathrm{mg} \mathrm{kg}^{-1}\right)\end{array}$ & $\begin{array}{c}\text { Limites } \\
\text { de } \\
\text { descarte } \\
\text { [43] }\end{array}$ \\
\hline DBO & $5000,00 \pm 0,01$ & $147,00 \pm 0,01$ & $58,00 \pm 0,01$ & $28,00 \pm 0,01$ & 60 \\
\hline DQO & $17000,00 \pm 0,05$ & $6836,00 \pm 0,05$ & $2501,25 \pm 0,05$ & $2397,59 \pm 0,05$ & ----- \\
\hline $\begin{array}{l}\text { Óleos e } \\
\text { Graxas }\end{array}$ & $9942,0 \pm 0,5$ & $890,0 \pm 0,5$ & $147,2 \pm 0,5$ & $92,17 \pm 0,5$ & 150 \\
\hline СOT & $11435,0 \pm 0,1$ & $5275,8 \pm 0,1$ & $3127,7 \pm 0,1$ & $2215,9 \pm 0,1$ & ------ \\
\hline $\begin{array}{c}\text { Sólidos } \\
\text { Totais }\end{array}$ & $11700,0 \pm 0,5$ & $6210,0 \pm 0,5$ & $5020,0 \pm 0,5$ & $4030,0 \pm 0,5$ & ------ \\
\hline \multicolumn{6}{|l|}{ Metais } \\
\hline $\mathrm{Zn}$ & $5,680 \pm 0,001$ & $0,090 \pm 0,001$ & $1,030 \pm 0,001$ & $2,430 \pm 0,001$ & 5,0 \\
\hline $\mathrm{Pb}$ & $0,310 \pm 0,001$ & nd & $0,080 \pm 0,001$ & $0,080 \pm 0,001$ & 1,5 \\
\hline $\mathrm{Ni}$ & $0,320 \pm 0,001$ & $0,040 \pm 0,001$ & nd & nd & 2,0 \\
\hline $\mathrm{Fe}$ & $31,400 \pm 0,001$ & $2,080 \pm 0,001$ & $2,310 \pm 0,001$ & $1,950 \pm 0,001$ & 15,00 \\
\hline Mn & $20,000 \pm 0,001$ & $12,000 \pm 0,001$ & $0,900 \pm 0,001$ & nd & 1,0 \\
\hline $\mathrm{Cu}$ & $1,750 \pm 0,001$ & $0,010 \pm 0,001$ & $0,360 \pm 0,001$ & $0,860 \pm 0,001$ & 1,5 \\
\hline $\mathrm{Cr}$ & $0,4420 \pm 0,001$ & $0,100 \pm 0,001$ & $0,060 \pm 0,001$ & $0,390 \pm 0,001$ & 5,0 \\
\hline
\end{tabular}

nd = não detectado

Portanto, de acordo com os dados da tabela, observa-se que com as condições dos experimentos 08 e 13, os efluentes estão dentro dos limites de descarte, o que limita a hidrólise ácida (Experimento 01) como um processo no tratamento de fluidos de corte. 
Na Figura 13 encontra-se uma comparação na redução do COT entre os experimentos 08 e 13, o experimento 08 apresenta uma redução mais acentuada no início da reação, porém a velocidade de oxidação diminui com o desenvolvimento da reação. O experimento 13 , por outro lado, possui uma redução no COT menos acentuada, porém devido à regeneração de íons ferrosos a oxidação continua com o passar do tempo.

O experimento 08 utiliza mais reagentes que o experimento 13 , porém o processo foto-Fenton (Experimento 13) apresenta a desvantagem de se utilizar lâmpada de UV-Vis. Dessa maneira, ambos os processos são comparáveis.

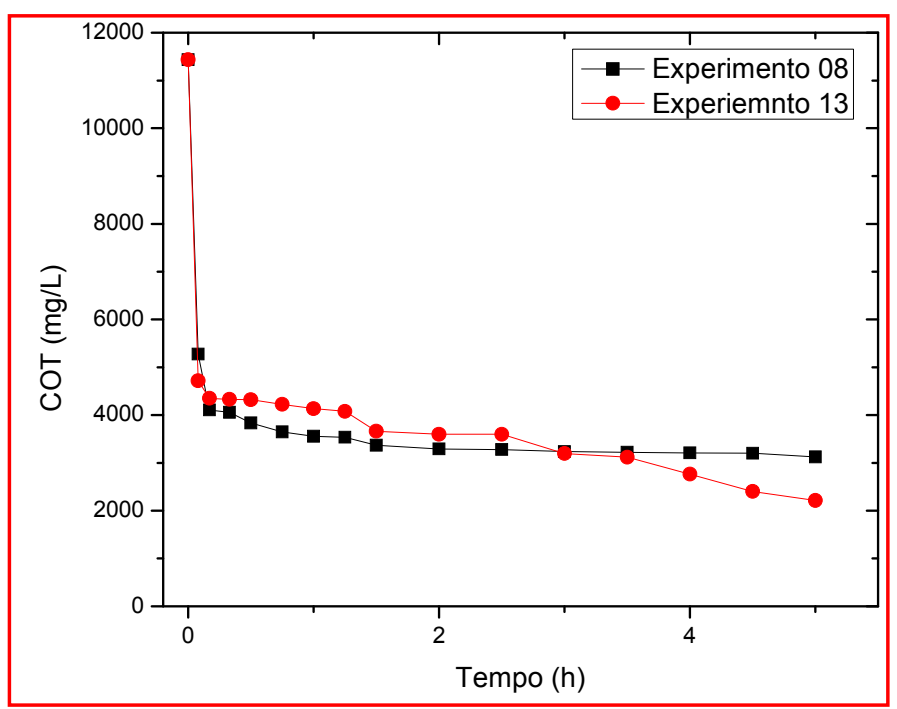

Figura 13: Comparação na redução do COT dos experimentos 08 e 13 em função do tempo.

A elevada eficiência do sistema foto-Fenton nos primeiros minutos de reação pode ser atribuída a uma elevada eficiência inicial do sistema Fenton, o qual, além de permitir a formação de um equivalente de radical hidroxila, leva à geração de íons férricos. Nas condições em que o processo é aplicado (solução aquosa e pH 3), os íons férricos encontram-se predominantemente na forma $\mathrm{Fe}(\mathrm{OH})^{2+}$, espécie que absorve notavelmente radiação de comprimento de onda maior que $300 \mathrm{~nm}$. A 
absorção de radiação leva à fotorredução dos íons férricos, com formação de íons ferrosos e geração de mais um equivalente de radical hidroxila. Este processo fecha um ciclo catalítico que maximiza a eficiência do processo degradativo [44].

A Tabela 16 apresenta os custos com o tratamento do fluido de corte pelo sistema Fenton e foto-Fenton nas melhores condições estudas, ou seja, nos experimentos 08 e 13.

Tabela 16: Custo estimado para cada tratamento estudado

\begin{tabular}{|c|c|c|c|c|c|}
\hline & \multirow[b]{2}{*}{ Custo } & \multicolumn{2}{|c|}{ Experimento 08} & \multicolumn{2}{|c|}{ Experimento 13} \\
\hline & & Consumido & $\begin{array}{l}\text { Valor } \\
\text { gasto }\end{array}$ & Consumido & $\begin{array}{l}\text { Valor } \\
\text { gasto }\end{array}$ \\
\hline $\begin{array}{l}\mathrm{H}_{2} \mathrm{SO}_{4} \\
\text { (conc.) }\end{array}$ & $\begin{array}{c}\mathrm{R} \$ 0,014 / \\
\mathrm{mL}\end{array}$ & $2,5 \mathrm{~mL}$ & $\begin{array}{c}\mathrm{R} \$ 0,035 / \\
\mathrm{L}\end{array}$ & $2,5 \mathrm{~mL}$ & $\begin{array}{c}\mathrm{R} \$ 0,035 / \\
\mathrm{L}\end{array}$ \\
\hline $\begin{array}{c}\mathrm{FeSO}_{4.7 \mathrm{H}_{2} \mathrm{O}} \\
\text { (p.a.) }\end{array}$ & $\begin{array}{c}\mathrm{R} \$ 0,010 / \\
\mathrm{g}\end{array}$ & $1,4 \mathrm{~g}$ & $\begin{array}{c}\mathrm{R} \$ 0,014 / \\
\mathrm{L}\end{array}$ & $0,278 \mathrm{~g}$ & $\begin{array}{c}\mathrm{R} \$ 0,00278 / \\
\mathrm{L}\end{array}$ \\
\hline $\begin{array}{l}\mathrm{H}_{2} \mathrm{O}_{2} \\
(30 \mathrm{~V})\end{array}$ & $\begin{array}{l}\mathrm{R} \$ 0,005 / \\
\mathrm{mL}\end{array}$ & $13,6 \mathrm{~mL}$ & $\begin{array}{c}\mathrm{R} \$ 0,068 / \\
\mathrm{L}\end{array}$ & $13,6 \mathrm{~mL}$ & $\begin{array}{c}\mathrm{R} \$ 0,068 / \\
\mathrm{L}\end{array}$ \\
\hline $\begin{array}{l}\mathrm{NaOH} \\
\text { (satur.) }\end{array}$ & $\begin{array}{c}\mathrm{R} \$ 0,005 / \\
\mathrm{mL}\end{array}$ & $5,4 \mathrm{~mL}$ & $\begin{array}{c}\mathrm{R} \$ 0,027 / \\
\mathrm{L}\end{array}$ & $4,8 \mathrm{~mL}$ & $\begin{array}{c}\mathrm{R} \$ 0,024 / \\
\mathrm{L}\end{array}$ \\
\hline $\begin{array}{l}\text { Energia* } \\
\text { Elétrica }\end{array}$ & $\begin{array}{c}\mathrm{R} \$ 0,22466 / \\
\mathrm{kWh}\end{array}$ & ------ & ------ & $1,25 \mathrm{kWh}$ & $\mathrm{R} \$ \mathrm{~L}$ 0,0624/ \\
\hline TOTAL & & & $\begin{array}{c}R \$ 0,17 / \\
L\end{array}$ & & $\begin{array}{c}R \$ 0,19 / \\
L\end{array}$ \\
\hline
\end{tabular}

Agência Nacional de Energia Elétrica-ANEEL, média do custo da energia elétrica para empresas no período de julho de 2007.

O gasto de energia elétrica de $1,25 \mathrm{kWh}$ foi para o tratamento de $4,5 \mathrm{~L}$ de resíduo, portanto o valor de $\mathrm{R} \$ 0,0624$ está computado para o tratamento de $1 \mathrm{~L}$.

Os valores finais de tratamento estão diferindo em $R \$ 0,02$, o que para uma empresa de pequeno porte que possui em torno de $10000 \mathrm{~L}$ de fluido passivo para ser tratado representa uma diferença considerável $(R \$ 200,00)$. Por outro lado o sistema foto-Fenton precisa ser melhor avaliado, pois se esse mesmo sistema 
possuir a capacidade de tratar volumes acima 8,370L, o processo foto-Fenton será mais econômico que o processo Fenton. 


\section{CAPÍTULO 8:}

\section{CROMATOGRAFIA}

Figura 14 apresenta o cromatograma obtido do fluido de corte antes e
após o mesmo ser utilizado no processo de usinagem. O fluido de corte apresenta BTEX ou HPAs em sua formulação (1 e 2), porém, a contaminação pelo óleo presente na peça usinada e a alta temperatura na região de contato peçaferramenta causa a contaminação ou a formação de compostos tóxicos que pode ser observado nos cromatogramas de BTEX e HPAs após o processo de usinagem (3 e 4). 


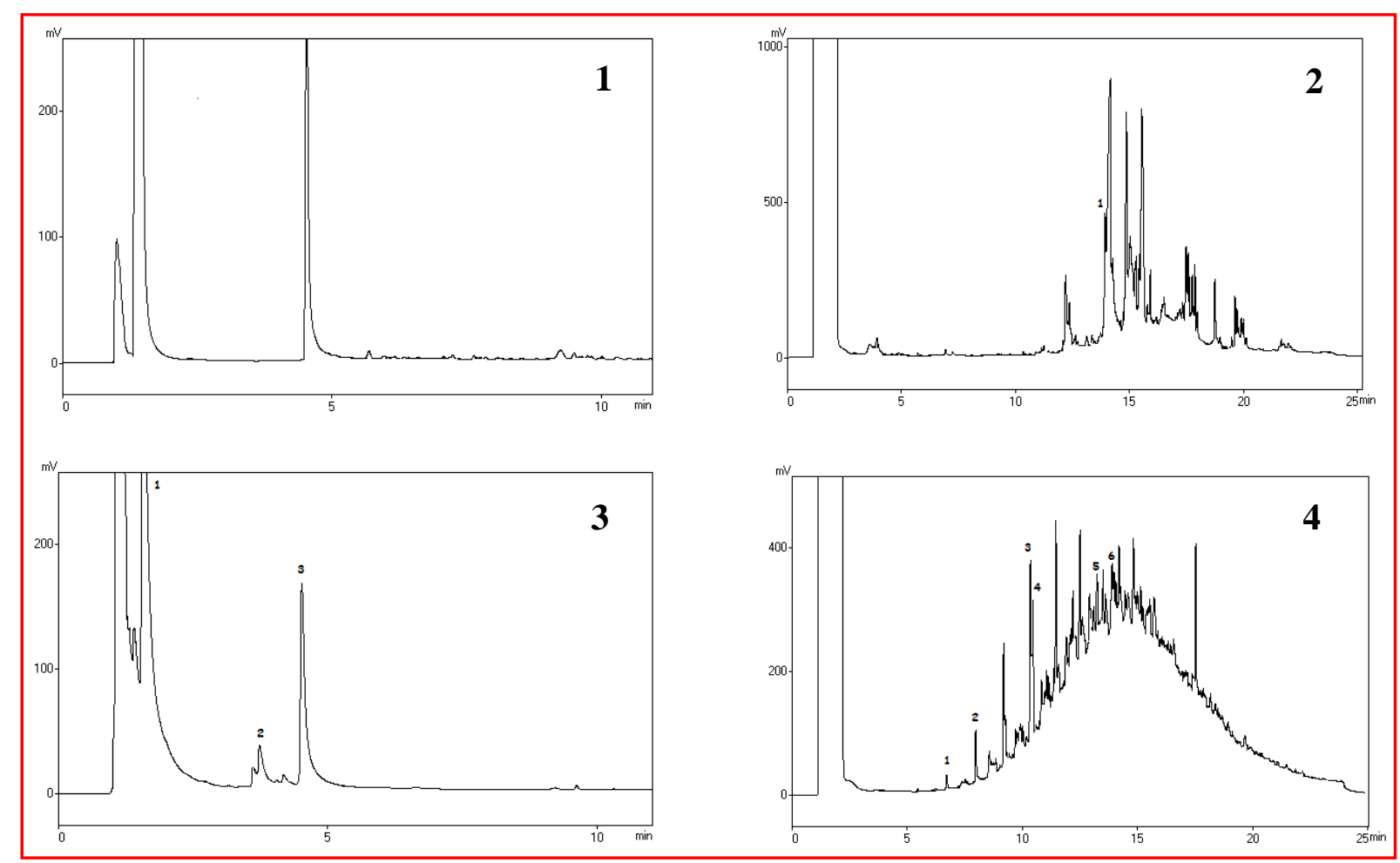

Figura 14: Análise de BTEX e HPAs antes e após o processo de usinagem: 1 e 2 fluido de corte antes do processo de usinagem - BTEX e HPAs respectivamente; 3 e 4 fluido de corte após o processo de usinagem - BTEX e HPAs respectivamente.

Para o fluido de corte antes do processo de usinagem: no cromatograma 1 encontra-se uma concentração de $29,31 \mathrm{mg} \mathrm{L}^{-1}$ de xileno (o) (pico 1) e 15,8586 mg $\mathrm{L}^{-1}$ de pireno (pico 1) no cromatograma 2. Esses compostos também estão presentes no resíduo de fluido juntamente com outros compostos.

O fluido de corte destinado ao descarte apresentou os seguintes compostos e concentrações (Tabela 17 e 18). 
Tabela 17: Concentrações de BTEX no resíduo de fluido de corte

BTEX

\begin{tabular}{|c|c|c|c|c|c|}
\hline \multicolumn{3}{|c|}{ BTEX } & \multicolumn{3}{|c|}{ HPAs } \\
\hline Pico & Composto & Conc. (mg L-1) & Pico & Composto & Conc. $\left(\mathrm{mg} \mathrm{L}^{-1}\right)$ \\
\hline 1 & Benzeno & 107,0869 & 1 & Acenafteno & 10,6791 \\
\hline 2 & Etilbenzeno & 5,2949 & 2 & Fluoreno & 45,6844 \\
\hline \multirow[t]{4}{*}{3} & Xileno (o) & 10,27 & 3 & Fenantreno & 103,7531 \\
\hline & & & 4 & Antraceno & 70,2600 \\
\hline & & & 5 & Fluoranteno & 109,9124 \\
\hline & & & 6 & Pireno & 120,1975 \\
\hline
\end{tabular}

Tabela 18: Concentração de HPAs no resíduo de fluido de corte

Os resultados da análise de HPAs dos experimentos 08 a 13 encontram-se na Figura 15, os resultados obtidos nos testes de foto-Fenton foram melhores que os testes realizados no sistema Fenton. No primeiro não há a extração de HPAs, enquanto que no sistema Fenton não só foi detectada a presença (Experimento 09) como também houve a extração de outros compostos presentes no efluente. A Tabela 19 apresenta os contaminantes encontrados no Experimento 09.

Tabela 19: Concentração de HPAs encontrados no Experimento 09

\section{HPAs}

\begin{tabular}{ccc} 
Pico & Composto & Conc. $\left(\mathbf{m g ~ L}^{-1}\right)$ \\
1 & Fluoreno & 5,2583 \\
2 & Fenantreno & 14,7450 \\
3 & Antraceno & 10,1117 \\
4 & Fluoranteno & 15,0334 \\
\hline
\end{tabular}



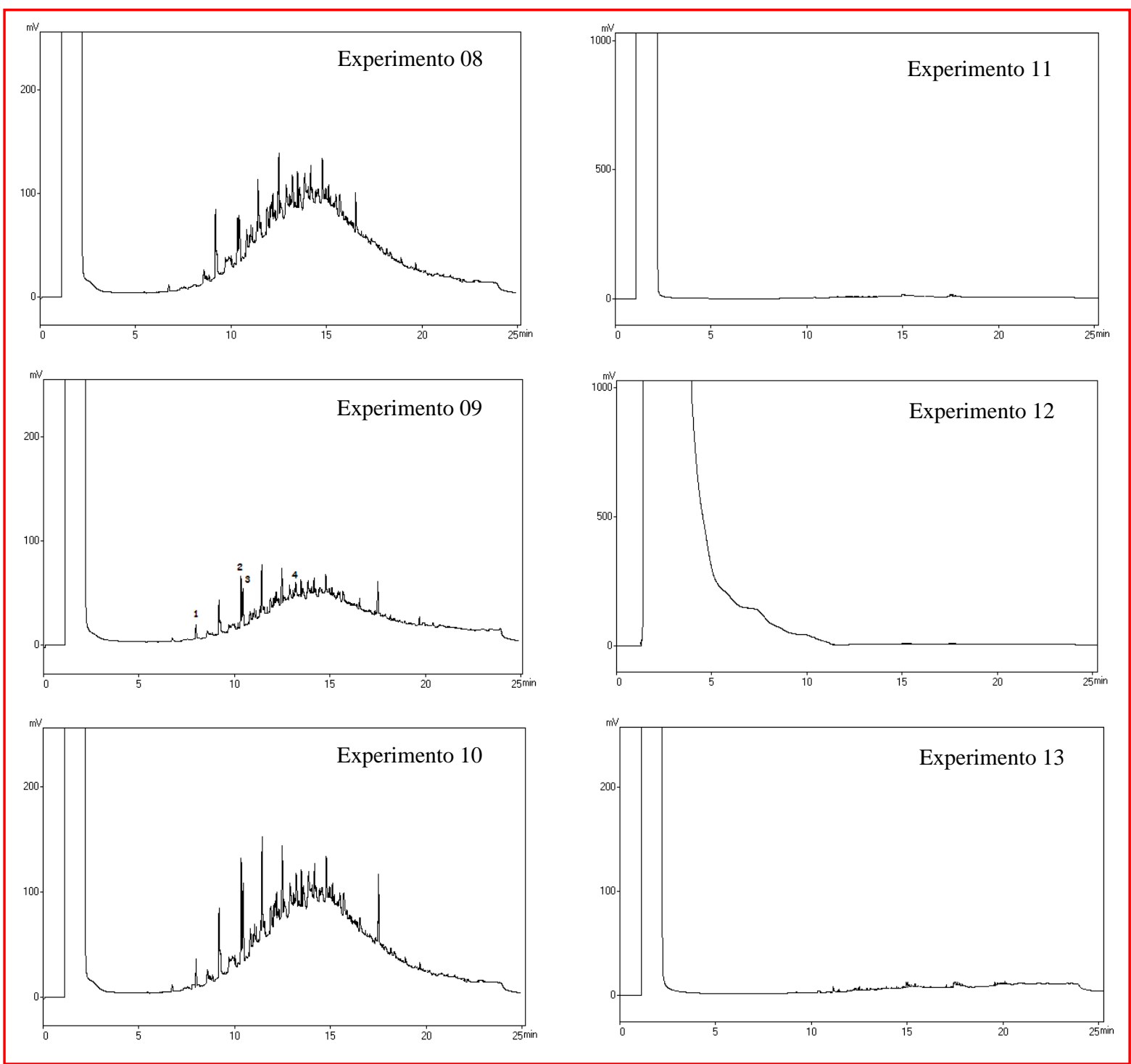

Figura 15: Análise de HPAs para os experimentos utilizando Fenton (Experimento 08, 09 e 10) e Foto-Fenton (Experimento 11, 12 e 13).

Para a análise de BTEX, Figura 16, os dois processos não apresentaram picos dos compostos estudados. Os cromatogramas obtidos para ambos os processos são equivalentes não havendo outros compostos voláteis, como no caso dos HPAs. Na análise de HPAs, faz-se o uso de extração por meio de solvente, dessa forma, existindo outro composto que possa ser extraído, ele originará um pico no espectro. No caso do BTEX, como há aquecimento da amostra e não extração, todos os compostos voláteis presentes são analisados. Provavelmente, os compostos voláteis são mais facilmente degradados. 

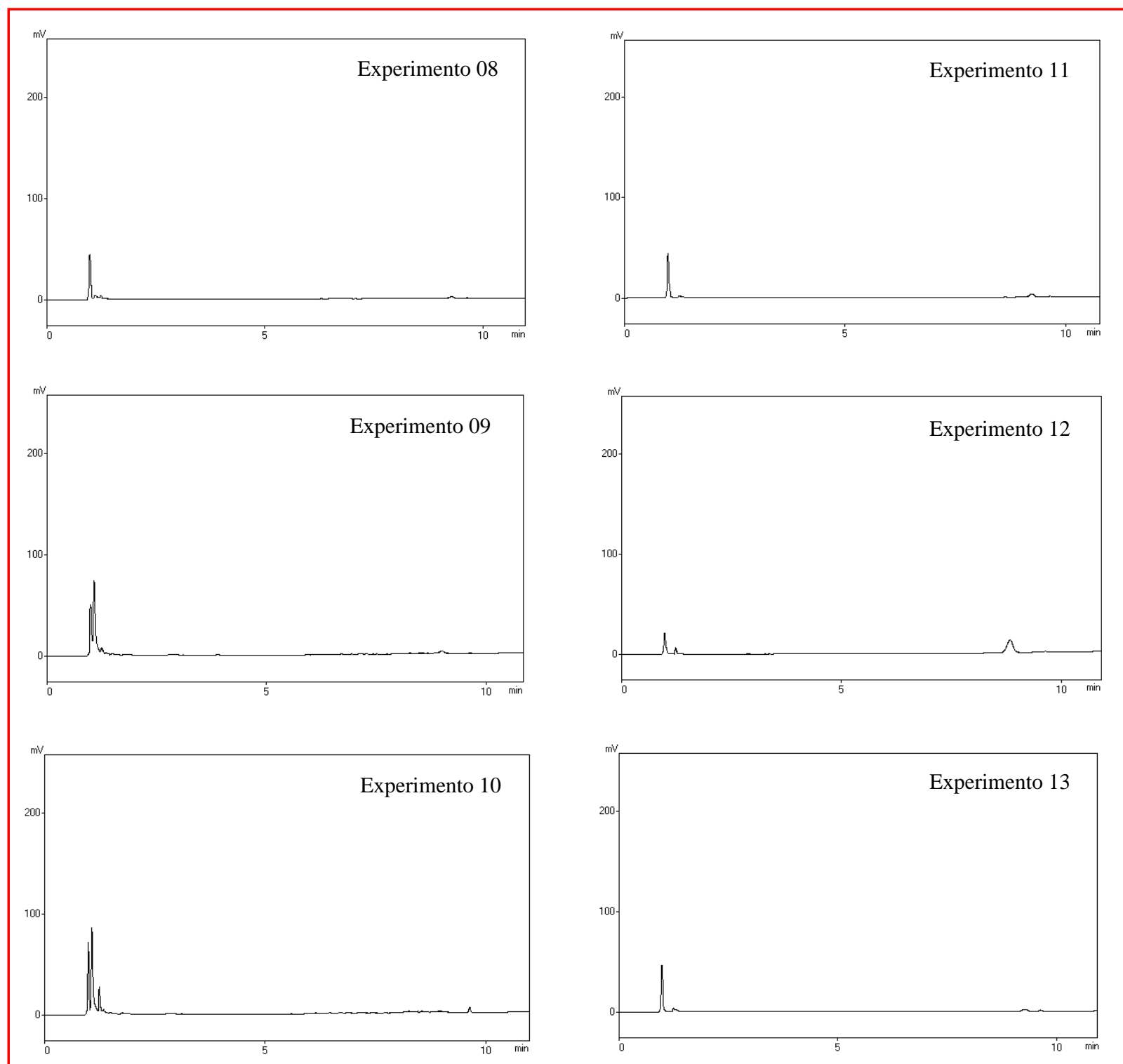

Figura 16: Análise de BTEX para os experimentos utilizando Fenton (Experimento 08, $09 \mathrm{e}$ 10) e Foto-Fenton (Experimento 11, 12 e 13).

A Figura 17 apresenta a análise de nitrosaminas do fluido de corte antes e após o mesmo ser utilizado no processo de usinagem. Observa-se que após o processo de usinagem há uma grande quantidade de compostos que foram formados ou agregados à solução durante o processo. Essa grande quantidade de compostos dificulta a interpretação dos cromatogramas, mas a análise dos 
resultados não revelou a presença de nitrosaminas após o processo de usinagem para o fluido em questão.

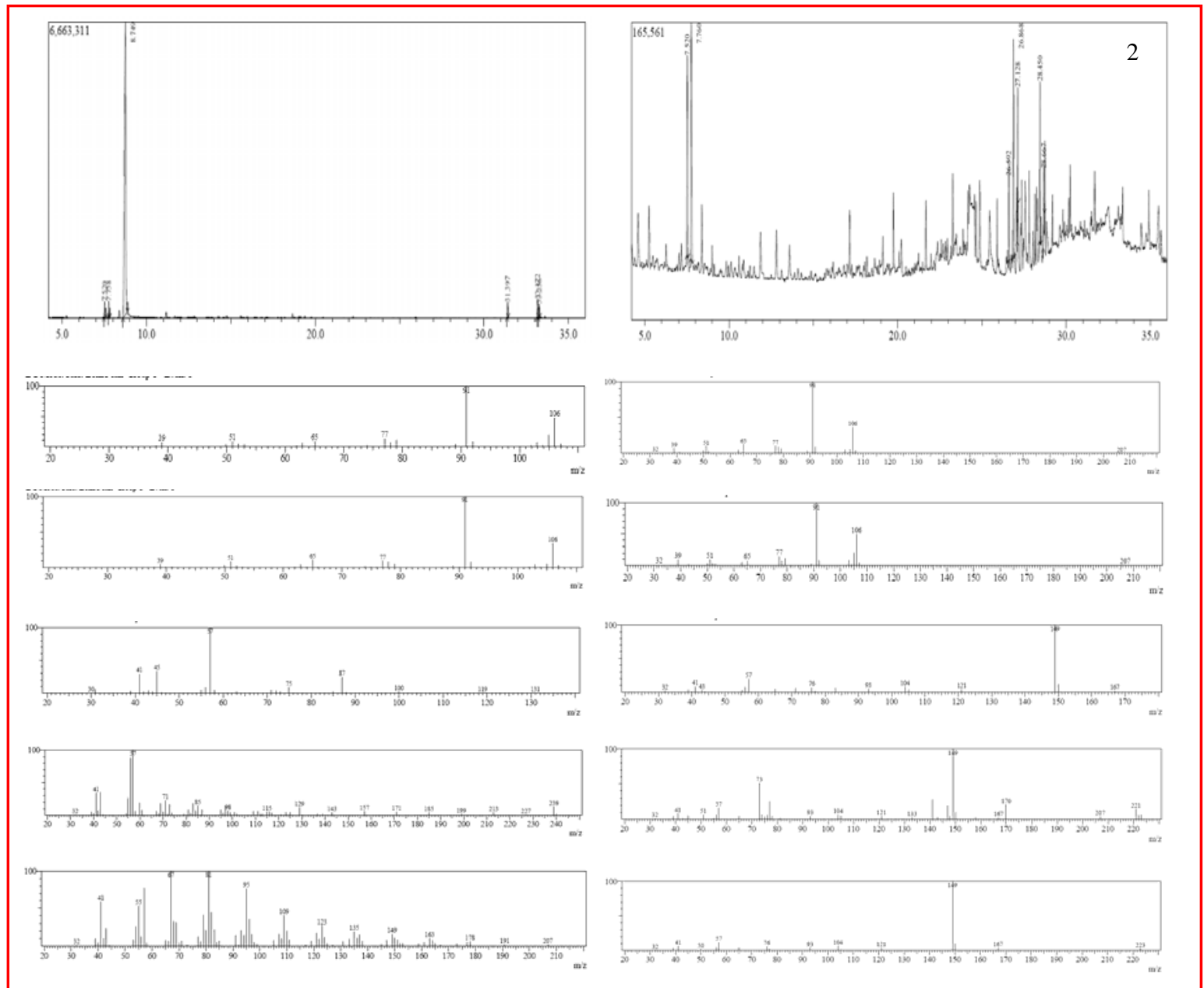

Figura 17: Cromatograma de amostras de fluido de corte antes (1) e após (2) o processo de usinagem, os espectros de massa estão abaixo de cada cromatograma e representam os cinco primeiros picos do espectro.

A Figura 18 apresenta os cromatogramas do fluido de corte tratado de acordo com os Experimentos 8 ao 13. 


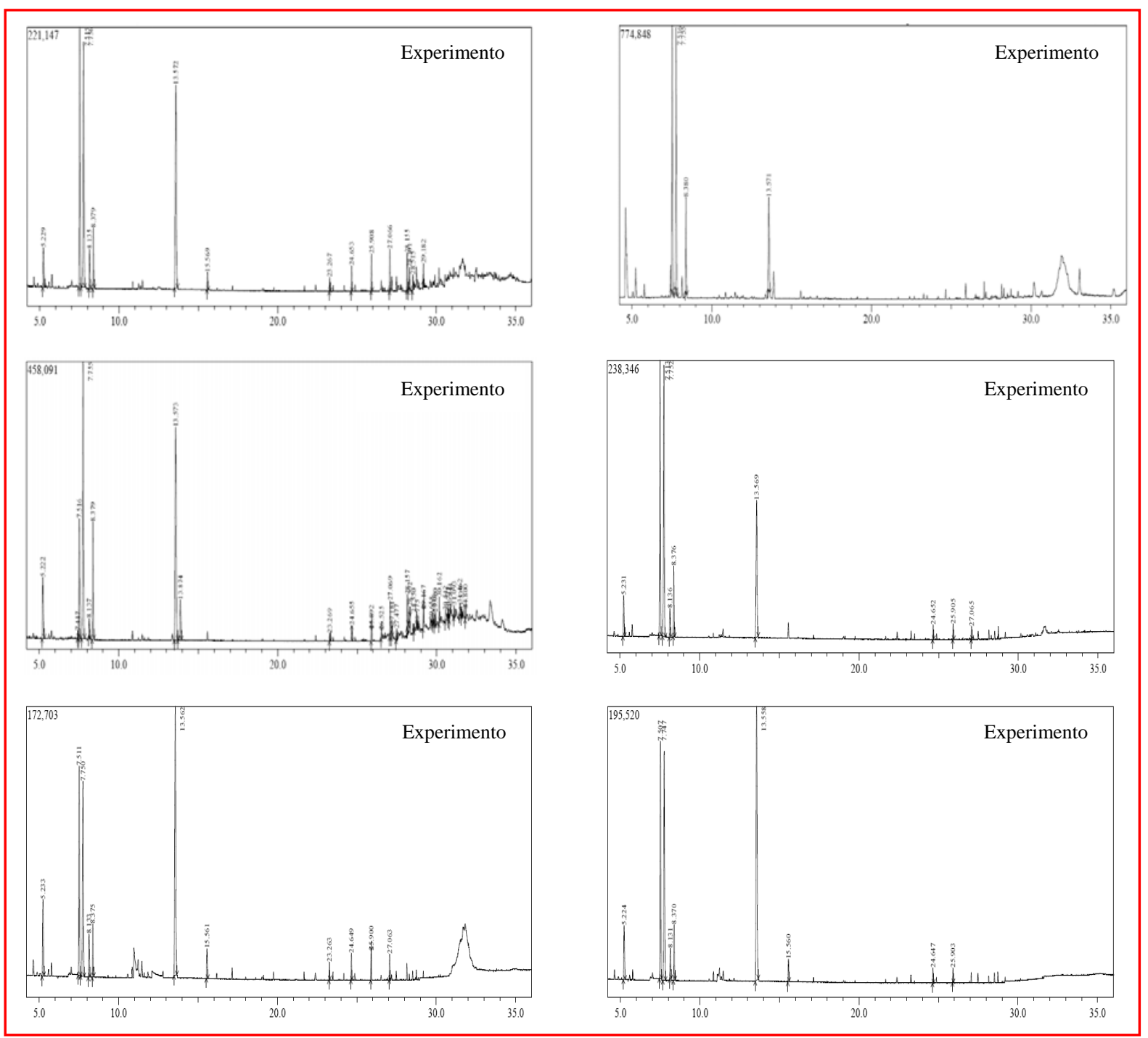

Figura 18: Cromatograma dos Experimentos 09 ao 13, onde não foi observado a presença de nitrosaminas.

Como era de esperar os cromatogramas dos Experimentos 08 ao 13 não apresentaram picos referentes às nitrosaminas (Figura 18) apesar de haver grande quantidade de compostos. Pelo fato de não terem sido identificados nitrosaminas e sendo os cromatogramas muito parecidos, não há como avaliar qual método é mais eficiente na remoção de nitrosaminas. 


\section{CAPÍTULO 9:}

\section{CONCLUSÕES}

falta de informações bibliográficas sobre a composição ou mesmo
sobre processos de descarte de fluidos de corte dificultou a realização deste trabalho.

Devido às altas temperaturas na região do corte, o fluido apresentou decomposição térmica, o que pode ser verificado na redução dos parâmetros orgânicos analisados. Outro fato que chamou a atenção foi a presença de chumbo e cromo nas ligas metálicas utilizadas no processo de usinagem.

O processo de hidrólise ácida, recomendada por muitos fabricantes de fluido de corte, não apresentou grande redução na carga orgânica da solução e os valores de óleos e graxas e Mn encontraram-se acima dos limites de descarte permitidos pela legislação.

O sistema foto-Fenton demonstrou-se mais eficiente que o sistema Fenton, na degradação de BTEX e HPAs. Nos cromatogramas da análise de HPAs para o tratamento utilizando o sistema foto-Fenton não se detectou a presença de outros compostos solúveis na fase extratora.

As nitrosaminas não foram detectadas nas amostras de fluidos de corte estudas, dessa forma não se pode avaliar a eficiência na remoção das mesmas. 
Os processos oxidativos avançados apresentaram resultados satisfatórios no tratamento de fluidos de corte, a escolha de um ou outro método vai depender de mais alguns testes a serem realizados no sistema foto-Fenton e/ou da disponibilidade financeira da empresa em questão. 


\section{CAPÍTULO 10:}

\section{SUGESTÕES PARA}

\section{TRABALHOS FUTUROS}

omo sugestão para trabalhos futuros propõe-se a construção de

sistema piloto para a destruição de fluidos de corte em média escala

(100 a 200L), dessa forma pode-se estudar o comportamento do sistema fotoFenton em volumes maiores.

Esse sistema piloto pode ser utilizado para o tratamento dos fluidos de corte em empresas de pequeno e médio porte. Através desse sistema será possível também o monitoramento da periculosidade dos resíduos de fluidos de corte descartado.

Outra sugestão é a utilização de um sistema foto-Fenton solar, onde seria trocada uma fonte artificial para fonte natural de energia, esse sistema poderia ser mais ambientalmente correto e menos oneroso. 


\section{CAPÍTULO 11: \\ REFERÊNCIAS \\ BIBLIOGRÁFICAS}

1. DIAS, A.M.P., BRETANO, D. M., CARVALHO-PINTO, C. R. S., MATIAS, W. G. , Avaliação da toxicidade aguda de fluidos de corte utilizados em processos de usinagem usando como organismo-teste Poecilia reticulada e Daphnia magna. Revista do Centro de Ciências Biológicas da UFSC, v. 19, p. 7 - 13, 2006.

2. LEGRINI, O., OLIVEROS, E. BRAUN, A. M., Photochemical Processes for Water and Treatment. Chemical Review, v. 93: p. 671-698, 1993

3. Ollis, D.F., Heterogenous photocatalysis in the environment: aplication to water purification. Photocatalysis: Fundamentals and Aplications: p. 604-637, 1989

4. DAVIS, A.P. Removal of phenols from water by a photocatalytic oxidation process. Water Science Technology, v. 21: p. 455-464, 1989.

5. NEBEL, B. J. The Way the Word Works. Environmental Science: p. 345-368, 1996

6. SILVA, D.N., Degradação Fotoquímica de Hidrocarbonetos da Gasolina em Efluentes Aquosos. 2002. Departamento de Engenharia Química. 2002.

7. BRASIL, Lei Federal $n^{\circ}$ 9.605, de 12 de fevereiro de 1998, que dispõe sobre as sansões penais e administrativas derivadas de condutas e atividades lesivas ao meio ambiente, e dá outras providencias. 
8. HEYMEYER, T., Prospecção de Oportunidades para a Otimização dos Processos de Usinagem na Pequena e Média Empresa em São Carlos 2006. Departamento de Engenharia de Produção. 2006.

9. CATAI, R.E., BIANCHI, E. C., SILVA, D. C., PIUBELI, F. A., AGUIAR, P. R., Dermatose, um sério problema para a saude dos trabalhadores dentro das indústrias, in XI SIMEP. 2004: Bauru-SP.

10. COX, R.D., FRANK, C. W. Determination of Total N-Nitroso Content in Cutting Fluids. Analytical Chemistry, v. 54: p. 557-559, 1982.

11. CAKIR, O., YARDIMEDEN, A. , OZBEN, T. , KILICKAP, E. , Selection of Cutting Fluids in Machining Processes. Journal of Achievements in Materials and Manufacturing Engineering. 25(2): p. 99-102, 2007

12. Runge, P.R.F.D., G. N., Lubrificantes nas Indústrias - Produção, manutenção e controle Triboconcept - Edições Técnicas: p. 71-171, 1990

13. Commitee, A.I.H., Metal Handbook. 6 edição(Cap. 27): p. 14-16.1991

14. Webster, J., Selection of Coolant type and application technique in grinding. Supergrind: p. 205-218, 1995

15. SALES, W.F., DINIZ, A. E., MACHADO, Á. R., Application of cutting fluids in machining processes. J. Braz. Soc.Mech. Sci. 23(2), 2001

16. Maniasso, N., Ambientes miscelares em química analítica. Química Nova. 24, 2001

17. EL BARAIDE, M.A., Cutting fluids: Part I: Characterization. . Journal of Materials Processing Technology. 56: p. 786-797, 1996

18. QUEIROZ, J.L.L., Desenvolvimento de um protótipo de software para controle variável ambiental na utilização do fluido de corte. 2001. 188f. Tese de Doutorado - Departamento de Engenharia de Produção, Universidade Federal de Santa Catarina, Florianópolis. 2001.

19. ESTADOS UNIDOS. Metalworking Fluids: Safety and Health Best Pratices Manual. Disponível em:

<http://www.osha.gov/SLTC/metalworkingfluids/metalworkingfluids_man ual.html> acessado em 16/10/2007 às 16:25h. 
20. Sanz J., L.J.I., De Luis, A. M., Ortueta M., Verona, F. , Microwave and Fenton's reagent oxidation of wastewater. Environmental Chemistry: p. 45-50, 2003

21. PICOT, A., GRENOUILLET, P. , Safety in the chemistry and biochemistry laboratory. VCH Publishers, 1994

22. ALBERTINI, L.A.S., L. C.; REZENDE, M. O. O., Tratamento de resíduos químicos: guia prático para solução dos resíduos químicos em instituições de ensino superior. Vol. 1. 2005, São Carlos.

23. SANZ, J., LOMBRANA, J. I., DE LUIS, A. M., ORTUETA, M., VERONA, F. , Microwave and Fenton's reagent oxidation of wastewater. Environmental Chemistry: p. 45-50, 2003

24. JARDIM, W.F., Fundamentos de Oxidação Química no Tratamento de Efluentes e Remediação de Solos.

25. NEYENS, E., BAEYENS, J., A review of classic Fenton's peroxidation as an advanced oxidation technique. Journal of Hazardous Materials. B98: p. 33-50, 2002

26. Moraes, J.E.F.S., D. N.; Quina, F. H.; Chiavone Filho, O.; Nascimento, C. A. O., Utilization of Solar Energy in the Photodegradation of Gasoline in Water and of OilField-Produced Water. Environ. Sci. Technol. . 38: p. 3746-3751, 2004

27. NEUMANN, M.G., QUINA, F. H., A fotoquímica no Brasil. Química Nova. 25(1): p. 34-38, 2002

28. NOGUEIRA, R.P., TROVÓ, A. G., SILVA, M. R. A., VILLA, R. D., OLIVEIRA, M. C., Fundamentos e aplicações ambientais dos processos Fenton e foto-Fenton.

Química Nova. 30(2): p. 400-408, 2007

29. GROMBONI, C.F., FERREIRA, A. G., KAMOGAWA, M. Y., NOGUEIRA, A. R. A., Avaliação da Reação Foto-Fenton na Decomposição de Resíduos de Carrapaticida.

Química Nova. 30(2): p. 264-267, 2007

30. TAUCHERT, E., Degradação de Espécies Organocloradas por Processos Avançados Envolvendo Ferro Metálico. 2006. Departamento de Ciências Exatas 2006.

31. KIWI, J., LOPEZ, A., NADTOCHENKO, V., Mechanism and Kinetics of the OHRadical Intervention during Fenton Oxidation in the Presence of a Significant Amount 
of Radical Scavenger (Cl-). Environmental Science \& Tecnology. 34: p. 21622168,2000

32. ROSSETTI, G.H., ALBIZZATI, E. D., ALFANO, O. M., Decomposition of Formic Acid in a Water Solution Employing the Photo-Fenton Reaction. Industrial \&

Engineering Chemisty Research. 41: p. 1436-1444, 2002

33. PARK, J.H., CHO, I. H., CHANG, S. W, Comparison of Fenton and Photo-Fenton Processes for livestock wastewater treatment. Journal of Environmental Science and Health B41: p. 109-120, 2006

34. MURANAKA, C.T., Tratamento de efluentes contendo fenol através de processos oxidativos avançados (POA's). 2006. Escola Politécnica. 2006.

35. KOLTHOFF, I.M., MEDALIA, A. I., Reactions of ferrous iron whith hydrogen peroxide in absence of oxygen. Journal of American Chemistry Society: p. 37773783, 1949

36. Standard Methods for the Examination of Water and Wastewater, 20th edition.

37. MELQUIADES, R.A., LOBO, I. , GUEDES, C. L. B. , PINTO, J. P., Análise de benzeno, tolueno, etilbenzeno e xilenos em solos por headspace e cromatografia gasosa/detector de ionização de chama. Semina: Ciencias Exatas e Tecnológicas. 27(2): p. 113-120, 2006

38. NETTO, A.D., DIAS, A. E. X. , MOREIRA, J. C. , ARBILLA, G. , FERREIRA, L. F. V. , OLIVEIRA, A. S. , BAREK, J. , Avaliação da Contaminação Humana por Hidrocarbonetos Policíclicos Aromáticos (HPAs) e seus derivados nitrados (NHPAS): uma revisão Metodológica. . Química Nova. 23(6): p. 765-773, 2000

39. CAMARGO, M.C.R., TFOUNI, S. A. V. , VITORINO, S. H. P. , MENEGÁRIO, T. F. , TOLEDO, M. C. F., Determinação de Hidrocarbonetos Policíclicos Aromáticos (HPAS) em Guaraná em Pó (Paullinia cupana). Cienc. Tecnol. Aliment. 26(1): p. 230-234, 2006

40. CASTRO, A.M., CASTILHOS, Z. C. , LIMA, C. A. , Avaliação de Riscos à Saúde Humana por Exposição a HPAs Encontrados em Poeiras das Ruas de Niterói. XIII Jornada de Iniciação Científica - CETEM,

41. FILHO, P.J.S., CARAMÃO, E. B. , ZANIN, K. D. , GARCIA, R. C. , VALCÁRCEL, M. , RIOS, A., Pré-Concentração de Nitrosaminas a Partir de Amostras Aquosas por 
Extração em Fase Sólida e Cromatografia Capilar Eletrocinética Micelar. Química Nova. 26(2): p. 193-196, 2003

42. BRASIL, Decreto $n^{\circ} 8.468$, de 8 de Setembro de 1976, que dispõe sobre a Prevenção e o Controle da Poluição do Meio Ambiente.

43. ASSOCIAÇÃO BRASILEIRA DE NORMAS TÉCNICAS. NBR 1004 - Resíduos Sólidos. 1987.

44. TIBURTIUS, E.R.L., PERALTA-ZAMORA, P., EMMEL, A. LEAL, E. S., Degradação de BTXS via Processos Oxidativos Avançados. Química Nova. 28(1): p. $61-64,2005$ 